Derleme Çalışması | Review Article

\title{
AVRUPA BİRLİĞİ’NDE GÜVENCELİ ESNEKLİK BAĞLAMINDA KIRILGAN KÜMELERE SOSYAL YARDIM VE HIZZMETLER
}

\author{
Social Benefits And Services For Vulnerable Groups In The European Union In \\ The Context of Flexicurity
}

\author{
Erhan GÜLCAN
}

Dokuz Eylül Üniversitesi, erhanglc@gmail.com

\section{$\ddot{\mathbf{O} z}$}

Sanayi Devrimi, 1929 Büyük Buhran, İkinci Dünya Savaşı, yetmişli yıllardaki petrol krizleri ve 2007-2008 küresel mali krizi gibi krizler sonrasında ekonomik yönetim ve ekonomi politikaları değişmiştir. Bu değişimler şüphesiz işgücü piyasalarının durumuna bağlı olarak gerçekleşmektedir. Anılan her dönemde işgücü piyasasındaki kırılgan kümeler değişmekte, ancak bu kümelerde yer alanların ortak özellikleri aynı kalmaktadır. Kırılgan kümede yer alanlar düşük gelir, yetersiz sosyal koruma, toplumsal alan ve çalışma yaşamı görece dışlanma ve bazı durumlarda marjinalleşme gibi özellikler göstermektedir. Bu anlamda, kırılgan kümelerin işgücü piyasalarında sosyal güvenlik sistemlerinin korumasına ve güvence düzeneklerine fazlaca gereksinimleri vardır. Öte yandan, Avrupa Birliği (AB) ülkelerinde kırılgan kümeler kadınlar, gençler, yaşlılar, işsizler ve göçmenlerdir. Kırılgan kümelere ülkeler tarafindan sağlanan sosyal yardım ve hizmetler sonucunda bu kümelerin kırılganlığının azalması ülkelerin refah devleti modellerine ve sahip oldukları sosyal güvenlik sistemine göre farklılıklar göstermektedir.

$\mathrm{AB}$ işgücü piyasalarında esneklik ve güvencenin bağdaştırılabilmesi için güvenceli esneklik gibi yeni stratejiler geliştirilmektedir. Küreselleşme ile birlikte $A B$ işgücü piyasalarında kadınların istihdama katılımlarının artması, nüfusun yaşlanması, aile yapısında değişimler gibi nedenlerle bakım hizmeti gereksinimi artmaktadır. AB işgücü piyasalarında esneklik ve güvencenin bağdaştırılması için sosyal yardım ve bakım hizmetleri anahtar öneme sahiptir. Bu anlamda çalışmada, küreselleşmenin etkisi birlikte AB'ye üye ülkelerde kırılgan kümelere özgü yardım ve bakım hizmetlerinin karşılanması incelenmektedir.

Anahtar Kelimeler: Güvenceli Esneklik, Küreselleşme, Sosyal Yardımlar, Bakım Hizmetleri, Çocuk Bakımı. 


\begin{abstract}
The Industrial Revolution, the Great Depression of 1929, the Second World War, the oil crises of the 1970s and the global financial crises of 2007-2008 have resulted in a change of economic management and economic policies. These changes undoubtedly occur due to the situation of the labor market. The vulnerable groups of the labor market have changed in each mentioned period, but the common characteristics of those in these groups have remained the same. Those in the vulnerable groups have characteristics such as low income, inadequate social protection, relative exclusion from the social and work fields, and in some cases marginalization. In this sense, vulnerable groups have a greater need for the protection of social security systems and the security mechanisms in the labor market. On the other hand, the vulnerable groups in European Union (EU) countries are women, the young, elders, the unemployed and immigrants. As a result of the social benefits and services provided to vulnerable groups by countries the reduction of the vulnerability of these groups vary according to the welfare state models of the countries and the social security system they have.
\end{abstract}

New strategies have been EU labour markets in order to reconcile of flexibility and security. Along with globalization, the need for care services is increasing in the EU labour markets due to the reasons such as increasing of women's employment participation, population aging, changes in family structure. Social benefit and care services have key importance in order to reconcile of flexibility and security in the EU labour markets. In this meaning, the study examines the compansate of benefits and care services peculiar to vulnerable groups with the effect of globalization in the EU member states.

KeyWords: Flexicurity, Globalization, Social Benefit, Care Services, Childcare.

\title{
1. Giriş
}

Avrupa Birliği’nde Güvenceli Esneklik Bağlamında Kırılgan Kümelere Sosyal Yardım ve Hizmetler adlı bu çalışma üç bölümde incelenmektedir. Küreselleşme ekonomik kurumları Birinci bölümde küreselleşmenin etkilediği işgücü piyasaları ve kırılgan kümeler incelenmektedir. Bu bölümde küreselleşmenin ekonomik ve sosyal yapıda yarattığı değişim ortaya konmaktadır. $\mathrm{Bu}$ değişimde göze çarpan aile yapısındaki değişimler, işgücünün kadınlaşması ve AB'ye üye ülkelerde nüfusun yaşlanması konusu ele alınmaktadır. 
İkinci bölümde güvenceli esneklik ve kırılgan kümeleri koruyan düzenlemeler ortaya konmaktadır. Bu koruma sistemi ele alınırken $\mathrm{AB}$ ülkeleri arasındaki sosyal güvenlik sistemleri arasındaki farklar incelenmektedir. $\mathrm{AB}$ ülkelerinde temelde sosyal güvenlik sistemleri Bismarck ve Beveridge olarak ayrılsa da, temel farklılıklar üye ülkelerin geleneklerinden ve çalışma ilişkilerinden kaynaklanmaktadır. AB işgücü piyasalarında güvenceli esneklik bağlamında güvence sağlayan sosyal güvenlik sistemleri ve kırılgan kümeler ilişkisi incelenmektedir. Diğer yandan işgücü piyasasındaki kırılgan kümeler tanımlanarak ayrıma gidilmektedir.

Üçüncü ve son bölümde üye ülkelerde kırılgan kümelere yönelik sosyal yardım ve hizmetler incelenmektedir. Kırılgan kümelere yapılan sosyal yardım ve hizmetler üye ülkelerin sosyal güvenlik sistemleri ve refah devleti modellerinin farkları anlatılmaya çalışılmaktadır. Üye ülkelerde yaşı bakımı ve çocuk bakımı konusunda yapılan uygulamalara ve farklılıklara yer verilmektedir.

$\mathrm{Bu}$ bağlamda çalışmada $\mathrm{AB}$ ülkelerinde var olan sosyal güvenlik sistemlerinin işgücünün özellikle kırılgan kümelerin korunması bakımından farklılıkların ortaya konması sahip oldukları refah devletlerine göre yapılmaktadır. Anglo Sakson refah devletlerinde bireyler korunma gereksinimlerini görece piyasadan sağlamaktadır. Kırılgan kümelerde yer alanları belirli koruma politikaları sağlamak yerine yoksulluk düzeyi düşük olanlara genel bir koruma sağlamaktadır. Bu anlamda yaşı bakımı için özel bir bakım sigorta dalı ya da sistem görece geliştirilmemiştir. Çocuk yardımları ise ailelerin yoksulluk düzeyine göre yapılmakta, kadınların işgücü piyasasına katılımları için gerekli gündüz bakım evi, kreş gibi ebeveynlerin çocukları bırakabilecekleri yaygın bir çocuk bakımı sistemi görece yoktur. Akdeniz türü refah devletlerinde kırılgan kümelere belirli koruma programları sağlanmamaktadır. $\mathrm{Bu}$ ülkelerde formel sosyal yardım ve hizmetler işgücü piyasasında korunan kümelere sağlanırken kırılgan kümelere sağlanmamaktadır. Güvenceler aile üzerinden enformel biçimde sağlanmaktadır. Akdeniz türü refah devletlerinde yaşlılar ve çocuklar için bakım sistemi sosyal güvenlik sistemleri içinde görece gelişmemiştir. 
Korporatist refah devletlerinin en önemli özelliği olan büyük işletmelerin ve güçlü işçi sendikalarının varlığı sosyal güvenlik sistemleri ile işgücü piyasası arasında eşgüdüm sağlamaktadır. Bu nedenlerle gerek duyulan güvenceler için sigorta dalları oluşturulmaktadır. Yaşlılar için bakım sigortası yaşlanan nüfus göz önünde bulundurularak önceden bir sigorta dalı olarak akçelendirilmesi sağlanmıştır. $\mathrm{Bu}$ anlamda başta Almanya olmak üzere Korporatist ülkelerde yaşl1lar için bakım sigortası kurulmuş ve geliştirilmiştir. Korporatist refah devletlerinin özelliği gereği işletmelerle işçi sendikalarının eşgüdümünde büyük işletmelerde oluşturulan kreşler çocuk bakımının temelini oluşturmaktadır. Bunun dışında eyaletlerdeki sosyal güvenlik kurumları ve yerel yönetimler aracılığı ile çocuk bakımı sağlanmaktadır. İskandinav (Kuzey) Sosyal Demokrat refah devletlerinde yüksek refah ve güvence düzeyi ile bireylerin, ailelerin ve toplumun gereksinimleri karşılanmaktadır. Yaşlı bakımı evrensel sosyal güvenlik sistemi içinde değerlendirilmekte ve yaşlılara içinde sağlık bakımı ve gelir güvencesi gibi sosyal yardım ve hizmetler yüksek düzeyde verilmektedir. $\mathrm{Bu}$ refah devleti türünde hükümetin ve işveren sendikalarının mali destek sağladığı çocuk bakımı ülkenin genelinde ve işçi sendikalarının gözetiminde ve katkılarıyla sağlanmaktadır. Çocuk bakımı için gündüz bakım evi, ebeveynlerin işte olduğu sürelerde çocukların bakılacakları çocuk evleri gibi son derece gelişmiş bir çocuk bakım sistemi vardır. Bu anlamda, Kuzey Sosyal Demokrat ve Korporatist refah devletlerinde kırılgan kümelere sağlanan sosyal yardım ve hizmetler gelişmişken, Anglo Sakson ve Akdeniz türü refah devletlerinde görece gelişmemiştir. $\mathrm{Bu}$ anlamda çalışmada işgücü piyasalarında kırılgan kümelerin bağdaştırılmasının Kuzey refah devletlerinde ve Korporatist refah devletlerinde yüksek olduğu, Anglo Sakson ve Akdeniz türü refah devletlerinde görece daha düşük olduğu ortaya konmaktadır.

\section{Küreselleşme ve İşgücü Piyasası}

İşgücü piyasaları mal piyasaları, sermaye piyasaları gibi salt alıcı ve satıcıların kararları sonucu işleyen piyasalar olarak değerlendirilmemelidir. Bu anlamda, işgücü piyasalarının özü insana dayanır ve üretim ilişkisi bu yönde şekillenir. İşgücü piyasalarında bir yandan ekonomik aktör olarak işletmelerin rekabet edebilmeleri 
sağlanırken, diğer yandan toplumun ve üretimin sürekliliği için insanın korunması gerekmektedir. AB'ye üye ülkeler özellikle On Beşler olarak adlandırılan ilk üye ülkeler çağdaş sosyal güvenlik sistemlerini oluşturarak işgücü piyasalarından kaynaklanan meydan okumalara yanıt vermeye çalışmaktadır.

\subsection{Küreselleşme ve İşgücü Piyasalarında Kırılgan Kümeler}

Küreselleşme ile birlikte sayı, süre ve şiddeti artan ekonomik durgunluk, ekonomik krizler, reformlar ve işgücü piyasalarının yeniden tasarlanmasından kadınlar, gençler, atipik çalışanlar özellikle de geçici çalışanlar ve göçmenler gibi temel kırılgan kümeler fazlaca etkilenmektedir. $\mathrm{Bu}$ nedenle güvenceli esneklik özellikle yarı nitelikliler ve niteliksizler, kadın, genç ya da yaşı işçiler, işsizler ya da göçmenlere odaklanan bir yaklaşımdır (Commission, 2010, s. 12). Küreselleşme bir istihdam edilenleri ve istihdam edilmeyenleri gerek olumlu gerekse de olumsuz etkilemektedir. Ancak genel olarak küreselleşmenin olumlu etkilerinden çok dar bir kümede yer alanlar faydalanırken, olumsuz etkileri çok geniş kümeleri zorlamaktadır. AB'nin refah devletleri olumsuz etkilenenler için koruma düzenlemelerinin niteliğini ve niceliğini artırmaktadır. Ancak bu durum refah devletlerinin geleceği için de meydan okuma oluşturmaktadır.

\subsubsection{Küreselleşmenin İşgücü Piyasasına Etkisi}

Küreselleşme sonucunda esnekliğin artmasına bağlı olarak, kısmi süreli çalışma, kısa süreli sözleşmeler ya da formel istihdamın dışında tutulan işgücünün taşeronlarca çalıştırılması nedeniyle işgücünün kırılganlığının artması işgücü üzerinde denetimleri artırmaktadır. Bu bağlamda işçiler işsizlik ve yoksulluk riski yerine eğreti çalışma koşulları ve düşük ücretleri kabul etme eğilimindedir. İşsiz ya da eksik istihdam edilen işgücünün yüksek oranlarda olması ve düşük ücretler, işgücüne yönelik denetim düzeyinin arttığını göstermektedir (Anner, 2015, s. 18).

Sanayileşme sonrası post Fordist rejim, nüfusta farklılaşmanın ve ayrışıklığın artması, yaşamda ve çalışmada da standartsızlaştırmanın artması olarak tanımlanabilmektedir. Eğitim düzeyi ve süresinin kapsamı genişletilmekte ve ileri 
eğitimin yanı sıra mesleki ve profesyonel eğitim hızla arttırılmaktadır. Bazı yaşam geçişleri çeşitli yaş gruplarında gecikmekte, uzun süre almakta ve artmaktadır. Evrensellik ve yaşamda birbirini takip eden düzenin dereceleri azalmaktadır. İstihdama giriş düzensiz ve istikrarsız hale gelmekte, ilk işe girenlerin sözleşmeleri genelde geçici süreli olmakta, işsizlik nedeniyle istihdam sık sık kesintiye uğramakta ve kuramsal eğitim ya da uygulamalı eğitim ya da işgücüne dahil olmaksızın geçen süreler artmaktadır. İş değiştirme oranı artmakta ve meslekler uzun süreli olmamaktadır. Meslekler büyük oranda istihdam eden işletmelerin ekonomik geleceğine bağlı hale gelmektedir. Meslek olanakların yukarı doğru seyretmesine rağmen, mesleki akıcılık aşağı doğru seyretmektedir. İşsizlik yaygın hale gelmekte ve daha çok kadınlar, göçmen işçiler, genç ve yaşlı işçiler üzerinde yoğunlaşmaktadır (Mayer, 2009, s. 7-8).

Küreselleşme işgücü piyasalarını düzensizleştirme (deregulation) yoluyla etkilemektedir. $\mathrm{Bu}$ işgücü piyasalarında başta iş yasaları olmak üzere iş ve gelir güvencesini içeren mevzuatı düzensizleştirme anlamına gelir. $\mathrm{Bu}$ düzensizleştirmenin sonucunda işgücü piyasalarının katmanlaşması artmaktadır. Bir yandan çekirdek işlerde çalışan yüksek nitelikli işgücüne işletmeler görece iş güvencesi ve yüksek ücretler sağlarken, diğer yandan çevre işlerde düşük nitelikli işgücü düşük ücretler, uzun çalışma saatleri gibi daha kötü çalışma koşullarına maruz kalmaktadır. Küreselleşme ve buna bağlı artan katmanlaşmadan işgücü piyasalarında en çok etkilenen kadınlar, gençler, yaşlılar, işsizler ve göçmenlerden oluşan kırılgan kümeler etkilenmektedir.

\subsubsection{Küreselleşmenin Kırılgan Kümelere Etkisi}

Seksenli yılların başlarında pek çok Avrupa ülkesinde işsizlik oranı artmış ve bu Avrupa ülkeleri işsizliğin mali sonuçlarını azaltmak için daha emek yoğun büyümeye bir dönüş yapılmasını uygun görmüşlerdir. Doksanlarda küreselleşme ve bireyselleşme süreçleri işgücü piyasasına kadın katılımının artması ve işçilerin ve işverenlerin çalışma koşullarını daha serbest belirlemesi gibi işgücü piyasasının arz ve talep yapılarında yeni değişiklikleri içermekteydi. Bununla birlikte, işsizlik ve 
bunun ekonomik ve sosyal yansımaları pek çok ülkede önemli sorunlara neden olmuştur (Reci \& Bruijn, 2006, s. 5).

Schmid'e göre (1998, s. 8) işsizlik sosyal dışlanmanın en önemli nedenidir. Sosyal dışlanma işsiz olma ya da işgücü piyasalarında küçük değişikliklerin gerçeğine gerek duymaksızın, bireyin özellikle işgücü piyasasından çekilmesine verdiği tepkiyle ilgilidir. Bu işçilerin vazgeçilebilir sayılması, çalışma toplumu için geçerli değildir. Vazgeçilebilir olmak her insanın aidiyetine ve öz bilincine zarar vermektedir. Bireyler için toplumsal rollere (baba, anne, ebeveyn, emekli vb.) geçebilmeye herhangi bir seçenek olmadığında ya da sağlanmadığında bu tür bir zararın etkisi en kötü biçimde kendini gösterir. İşsizlik riskiyle karşılaşanlar için yoğun iş arama hizmetinin birleştiği yardım sistemlerinin tasarlanmasında yenilikler ve işsizlerin iş arama yoğunluğunun yakın izlenmesi düşük işsizlik ve yüksek istihdam katılımına ulaşmayı sağlarken oldukça cömert yardımların sürekliliğini sağlar. Bu, işsizlere iş aramayı aktif duruma getirmeyi sağlayan önlemleri içermekte ve yeni bir iş bulmayı -aktif işgücü piyasası politikaları politikaları olarak anılan- teşvik etmektedir. $\mathrm{Bu}$ bağlamda, işsizlerin yardımlardan çok bir iş edinmeleri daha önemlidir (OECD, 2006, s. 10).

Gençlerin işgücü piyasalarına geçişleri karmaşık etmenlerin çeşitliliğine göre şekillenir. Eğitim kurumları ve eğitim düzeyleri işgücü piyasalarıyla gençlerin ilişkilerini etkilemektedir (Campbell, Kelly, \& Harrison, 2011, s. 12). Bütün gençlere işgücü piyasasında etkin yürütümün gereksinimi olan temel becerileri kazandırma amacında olan eğitim sisteminin hataları nedeniyle okul yaşamından iş yaşamına geçişler zorlaşmaktadır. Bu bağlamda etkin bir yaklaşım zorunlu okul yaşından daha önce, okul öncesi dönemde başarısızlığg önlemek için müdahaleler yapılmalıdır. Ayrıca, eğitimle iş deneyiminin birbirini izleyen ülkelerde -uygun seviyede belirlenen ücretlerle- genç işsizlik düşme eğilimindedir. Eğitim sistemi dışında da istihdamı hedefleyen programlar ve iyileştirici mesleki ve genel eğitim gençlerin iş bulmasına yardımcı olabilmektedir (OECD, 2006, s. 15-16). 
Gençler sosyal dışlanmanın en çok etkilediği ve en tehlikeli boyutta gerçekleştiği kırılgan kümedir. Bunun nedeni, kapasitelerini kanıtlamak/göstermek için kendilerine hiçbir zaman şans verilmemesidir. Ayrıca, bir boyutuyla geçlerin işgücü piyasasına katılımının engellenerek sosyal dışlanmayla karşılaşmaları, kültürel yaşam, uygun ekonomik refah ya da politik alanlarda marjinalleşmelerine neden olur (Schmid, 1998, s. 8). Gençlerin istihdam modelleri genel işgücü piyasalarından bağımsız değildir. Gençler zamanlarını iş ve okul arasında ya da Batı toplumlarında gittikçe artan sosyo-ekonomik belirsizlik nedeniyle işler arasında geçişlerde harcamaktadır. Birçok genç insan okuldan işe geçişlerde bir dizi zorlukla karşılaşmaktadır. Günümüzdeki dünya artan genç istihdam kriziyle yüzleşmektedir. Hem gelişmekte olan hem de gelişmiş ekonomiler her yıl işgücü piyasasına giren genç kadın ve erkek geniş kümeler için uygun ve sürdürülebilir işler yaratma meydan okumasıyla yüzleşmektedir (Campbell et al., 2011, s. 12).

\subsection{Küreselleşme ve Ekonomik ve Sosyal Yapıda Değişim}

Ekonomik politikalar, yapılar, kurumlar ve tercihler sosyal yapıyı sürekli biçimde değiştirmektedir. İnsanlık tarihi boyunca tarım toplumunda, sanayi toplumu ve bilgi toplumunda aile yapısı, kadının durumu ve nüfus yapısı birbirlerinden farklı biçimlerde kendini göstermektedir. $\mathrm{Bu}$ bağlamda, tarım toplumunda ailenin büyüklüğü, işlevi ve ebeveynlerin durumu, aile reisi durumu ve kim olacağı sanayi ve bilgi toplumundan farklıdır. Sanayi toplumundan başlayarak kadının ücretsiz aile işçiliğinden sanayi işçiliğine geçerek işgücü piyasalarına katılımı, bilgi toplumuna geçişle birlikte artmıştır. İşgücü piyasalarının feminizasyonu küreselleşme ile birlikte daha da artmakta ve bu durum pek çok bağlamda toplumsal yapıda değişimin katalizörü olmaktadır. Küreselleşme pekçok gereksinimleri ve değişimleri hem ortaya çıkarıp hem de artırmaktadır. Nüfusu giderek yaşlanan gelişmiş AB ülkeleri bu toplumsal değişimle karşı karşıyadır.

\subsubsection{Aile Yapısında Değişim}

İkinci Dünya Savaşı sonrası istihdamın normatif modeli, sürekli istihdamı sağlanan aile reisi için sosyal ücret ve diğer refah devleti ödemelerinin dışında fonların 
birikimi ve aile için gelirin üretildiği bir yapı öngörür. İşçilerin istihdamının yanı sıra, istihdam dişında sosyal ücret için oluşturulan fonlardan da yararlanması gerektiği öne sürülmektedir (Hassel, 2003, s. 146-147). Günümüz istihdam söylemine yön veren küreselleşmeden, diğer bir deyişle uluslararası rekabete ilişkin ideolojik tartışmaların dışında bireysel çıkarların ön plana çıktığı bir eğilimle birlikte aile ve demografik yapılarla ilgili değişim çağdaş sanayi toplumlarında istihdam sistemleri için yeni meydan okumalar yaratmaktadır. Uygarlık, rasyonelleşme ve farklılaşmanın tarihsel evreleri şimdi bireyselleşme olarak adlandırılan çağcıllaşmanın yeni unsuru tarafından sürdürülmektedir (Hassel, 2003, s. 146-147; Schmid, 1998, s. 2). Ayrıca, işsizliğin ve gizli işsizliğin yüksek düzeyi sosyal güvenlik bütçeleri ve işsizlik fonlarına baskı yapmaktadır. Bu baskılar var olan sosyal güvenlik sisteminin malileştirilmesini zorlamasının yanı sıra ücret pazarlığı ve sosyal güvenlik ödemeleri arasında kurulan dengeyi de zorlamaktadır. Değişen makro ekonomik durumlardan ve aile değerlerindeki değişmelerden kaynaklanan dişsal dengesizlikler sosyal güvenlik sistemine etki etmektedir (Hassel, 2003, s. 146147).

$\mathrm{Bu}$ anlamda önemli politika yönelimlerinden bağımsız olmamakla birlikte, kamu sorumluluğundan bireysel sorumluluğa doğru belirgin bir kayma olmakta, aynı zamanda sanayiden sıyrılma ve sanayisizleşme (deindustrialization) (Yeldan \& Y1ldırım, 2015, s. 65; Cesur, 2016, s. 5, 10 ve 44) bir sonucu olarak önceki refah devleti sağlayıcıları gibi aileler de önemli değişiklikler geçirmektedir. Aileler tek gelirli erkeğin ücretinde ve aldığı yardımlarda azalmayı kısmen kadın istihdamında büyük artış ile dengeleyebilmektedir ve bu durum iş ve aile yükümlülükleri arasında dengenin sağlanmasını zorlaştırmaktadır (Hemerijck, 2015, s. 245). Kadınların işgücüne katılımlarının giderek artması, iş ve özel yaşam arasında bağdaştırmanın zorunlu olmasına neden olmaktadır. $\mathrm{Bu}$, işçi haklarının bireyselleşmesine neden olabilmekte ve kadın çalışanlar artık erkek aile reislerinin sosyal güvenlik haklarına bağımlı olmamaktadır. Daha genel düzeyde değerlendirildiğinde, hakların aile düzeyinden çıkarak bireysel haklar olarak değerlendirilmesi istemi doğmuştur (Eurofound, 21 March 2007, s. 2). 
Liberal refah devletinde erkeğin aile reisi olarak görüldüğü ataerkil aile modeli baskınlığı nedeniyle İrlanda ve Birleşik Krallık’ta kadına daha çok aile içinde analık ve eş görevi yüklenmiştir. Bu ülkelerde analık izninin kısalığı, kreş ve çocuk bakımı sürelerinin kısalığı, analık süresince sosyal korumanın yetersizliği gibi nedenlerle kadınlar işgücü piyasasına atipik biçimde katılmaktadır. Korporatist model içinde Fransız refah devletinde işgücü piyasasının baskın özelliği gereği, kadınlar tam süreli biçimde işgücü piyasasına katılmaktadır. Fransız kadınları çocuklu ya da çocuksuz durumlarına göre ücret sistemiyle yatay yeniden dağıtım yoluyla sosyal güvenlik yardımlarından dolaylı olarak yararlanmaktadır. Fransız kadınları Birleşik Krallık ve İrlanda'ki hemcinslerinin tersine ataerkil aile yapısının zayıflığıyla kadın; eş, anne ve ücretli işçi olarak çoklu göreve sahip olduğu kabul edilmektedir (Vielle \& Walthery, 2003, s. 23-24).

\subsubsection{Kadınların İşgücü Piyasasında Katılımının Artması}

Günümüzde başta kadının yaşam boyu bir mesleki kariyere sahip olması ve kişisel bağımsızlığg gibi nedenler ile demografik ve aile davranışlarında bir değişim ve devrimin ortasındayız. Günümüzde, kadınlar için evlilik, daha az ekonomik gerekçeye ve daha fazla bireysel seçimlere bağlı bir konudur. $\mathrm{Bu}$, yeni ve daha az istikrarlı aile ve hanehalkı düzenlemelerinin artması anlamına gelmektedir. $\mathrm{Bu}$ bağlamda, bir çocuğun hem annesi, hem de babasıyla birlikte yaşaması giderek olasılık dışı olmaktadır. Bütün bunlar bireysel seçim özgürlüğünün yanı sıra güvencesizlikleri ve riskleri de beraberinde getirmektedir (Z. Erdut, 2004, s. 356360; Esping-Andersen, 2002, s. 3).

Kadınların okullaşma oranı ve istihdam olanaklarının artışı; ölüm oranlarında ve doğum oranlarında azalmaya neden olmaktadır. Genç kadınların sürekli doğum yapma ve çocuk yetiştirmeden sıkıntılar yaşaması ve okullaşma, bağımsız gelir ve sosyal statülerinin artması ile ailede söz sahibi olmaları gibi nedenlerle doğum oranlarında azalma olmaktadır. Günümüzde, aile konularında daha fazla cinsiyet eşitliği ve kadınların karar verme sürecinde dışlanmalarının tersine çevrilmesi söz konusudur. Ailede önemli sosyal değişmeler yaratılmasında kızların okullaşma 
oranının ve kadınlarda istihdam olanaklarının artması önemli rol oynamaktadır (Sen, June 2000, s. 42-43).

Ekonomik İşbirliği ve Gelişme Örgütü (OECD)'ye göre (OECD, 2006, s. 15) kadınlar vergi olumsuzlukları, aile destek politikalarının kötü tasarlanması ve kısmi süreli işlerin eksikliğinden dolayı engellerle karşılaşmaktadır. İkincil işçilerin vergi işlemleri çoğu ülkede kadın işgücünün istihdama katılımını bastırma eğilimindedir. Aynı zamanda çalışma ile aile sorumluluklarını băgdaştırmaya yardımcı olabilecek uygun ebeveyn izni hükümlerinin eksikliği de kadın işgücünün katılımını azaltmaktadır. Ayrıca, çocuk bakım maliyetlerinin yüksek olması kadının evin dışında bir iş aramasını olanaksız duruma getirmektedir. Bu maliyetler genel çocuk yardımlarının çocuk bakım desteğine çevrilmesiyle düşürülebilir. Ancak burada, çocuk yardımlarının aile yardımları gibi sosyal konuları çocuk bakım sübvansiyonlarından daha kolay hedeflemesi gibi bir politik ikilem vardır. Yani çocuk yardımları çocuk bakım yardımlarına göre daha sosyal kapsayıcılığı olan bir konudur.

\subsubsection{Nüfusun Yaşlanması}

Demografik değişim, Avrupa'nın çalışma çağındaki bireylerin sayısında azalma ya da durağanlığıyla büyüyen ekonomik baskılarla yüzleşme yönündedir. Bu istihdam oranlarında artışın gerekliliği anlamına gelirken, aynı zamanda insanların işle aile yaşamını bağdaştırmayı teşvik etmesi anlamına da gelmektedir (Eurofound, 21 March 2007, s. 2).

İkinci Dünya Savaşı sonrası altın çağda AB ülkelerinde belirlenen emeklilik yaşı, günümüzde yaşam beklentisinin artması ve yaşlıların nüfus içinde artması ile beş ile yedi yıl arasında değişen sürelerde artırılmıştır. Doğum oranının azalması, sağlık alanındaki gelişmeler, işe ilişkin sosyokültürel bakışın değişimi, eğitim sürelerinin uzaması ile gençlerin işgücü piyasasına geç girişleri, işin yüksek yetkinlik ve uzun süreli deneyim istemesi gibi nedenlerden dolayı yaşlıların istihdam edilmesine gereksinim artmaktadır. Böylece, gelişmiş refah devletlerinde 45-65 yaş aralığı 
olarak tanımlanan orta yaştakiler ve 65 yaş üzerindeki yaşlıların ekonomik etkinliğe katılımında artı̧s olmuştur (Kanfer \& Ackerman, 2008, s. 160,166).

$\mathrm{AB}$ ülkelerinde nüfusun yaşlanma sürecinin ortaya çıkardığı gereksinimlere göre sosyal politikaların gelişimi sağlanarak kurumsal yapılanmalar oluşturulmaktadır (Bonoli, 2010, s. 9). Yaşlanma, refah devletinin bir meydan okuması olarak var olan sorunlar için hızlandırıcı etki yapmaktadır. Bütün sanayileşmiş ülkeler farklı derecelerde olsa da, yaşlanmayla ilgili sorunlarla yüzleşmektedir. 2030 yılına gelindiğinde Avrupa'da 65 yaş üstü kümenin oranı şimdiki oranından yüzde 50'den fazla artacaktır. $\mathrm{Bu}$ anlamda alanyazında salt ekonomik büyüme düşüncesine karşı olarak, $\mathrm{AB}$ ülkelerinin yaşlanan nüfusunun sosyal gereksinimlerinin finansmanı için ve yeni eğitim politikaları, çocuk bakımı, altyapı ve çevre gibi konularda ileriye dönük politikaların yaratılması için yeterli koşulların oluşturulmasına vurgu yapılmaktadır (Werner, 2006, s. 8).

\section{Güvenceli Esneklik ve Kırılgan Kümeler}

\subsection{Avrupa Birliği Ülekelerinde Sosyal Güvenlik Sistemleri}

$\mathrm{AB}$ ülkeleri refah devletlerinin oluşmasını sağlayan temel araç sosyal güvenlik sistemleridir. Başlangıçta işgücü piyasalarında karşılaşılan risklere ve yoksulluk riskine karşı güvence sağlayan bir sistem iken, zamanla nüfusun geneli için risk oluşturan konularda güvence sağlayan bir sisteme evrilmişir. AB refah devletleri bu risklere karşı oluşturdukları kurumsal yapılara ve geleneklere göre bir ayrıma gidilse de temel olarak sonuçta vatandaşlarının tümüne gelişmiş bir sosyal güvenlik düzeyi sunmaktadır.

\subsection{1. Üye Ülkelerde Sosyal Güvenlik Modelleri}

AB'ye üye ülkeler sosyal güvenlik sistemlerini genel olarak Bismarck ya da Beveridge sosyal güvenlik sistemine göre belirlemelerinin yanı sıra temel farklılık, refah devleti modellerinden kaynaklanmaktadır. AB'ye üye ülkelerde devlet müdahalesinin biçimine ve düzeyine göre refah devleti modelleri bağlamında sosyal 
güvenlik sistemleri dörde ayrılır. İlk olarak devletçi modelde devlet, refahı genel vergilerle sağlamadan sorumludur. İkincisi olan dayanışma temelli sosyal sigorta modelinde ise devlet işçi ve işverenlerin prim ödeme zorunluluğunda işçilerin sosyal risklere karşı sigortalanacağı düzenlemeyi sağlamaktadır. Üçüncüsü olan korporatist modelde de devlet, işçi sendikaları ve işveren örgütleri ya da işletme arasında yapılacak toplu sözleşme düzenini destekleme yoluyla refahı sağlamaktadır. Son olarak, yeni liberal ekonomik politikalar tarafından desteklenen bireysel çözümlere dayalı olarak, risklere karşı koruma özel sigorta yoluyla sağlanır, böylece devletin vergi indirimi ya da diğer imtiyazları sağlama rolü azaltılmış olur (Esping-Andersen, 1990, s. 25, 32; Rogowski, 2008, s. 20).

$\mathrm{Bu}$ anlamda, AB'nin genişlemesi ile birlikte, bütün Avrupa ülkeleri benzer riskler, gereksinimler ve mübadelelerle yüzleşmektedir. Piyasadan kaynaklı eşitsizliklerde artış her yerde vardır ve demografik değişimin belirtileri benzerdir. Günümüzdeki meydan okumalara, refah devletleri farklı sistemleriyle yanıt vermektedir, bu anlamda anılan rehaf devletlerinin yeni risklere etkin yanıt verebilme becerileri hem güçlü hem de zayıf yönlerine göre değişebilmektedir (Esping-Andersen, 2002, s. 13). Bismarck sosyal güvenlik sistemi tarafından desteklenen sosyal sigorta açıkça işçi sınıfı politikasının bir biçimidir. Temel olarak farklı sınıf ve statü kümeleri için ayrı programlar oluşturarak, her bireyin toplum içinde kendine özgü haklar ve imtiyazalar edinmesini desteklemiştir. Böylece, birey doğrudan devlet otortitesine bağlı tutulmuştur. $\mathrm{Bu}$ devletçi-korporatist model Almanya, Avusturya, İtalya ve Fransa gibi devletlerce sürdürülmektedir (Esping-Andersen, 1990, s. 24; Sözer, 1997, s. 7$8)$.

$\mathrm{AB}$ üyesi ülkeler Fordist dönemde Uluslararası Çalışma Örgütü (UÇÖ)'nün belirlediği sosyal güvenlik kurallarına uymakta ve işçileri ve tüm toplumu güvence altına almaktadır. UÇÖ’nün sözleşme ve tavsiyelerden oluşan çalışma standartları belirleme yöntemleri vardır. UÇÖ oluşturduğu standartlarla sözleşmeleri onaylayıp iç mevzuatlarına geçiren ülkelerde çalışma koşullarını uluslaarrası düzeyde belirlemektedir. $\mathrm{AB}$ refah devletlerinin düzenlemeleri bir yandan UÇÖ’ne rehber 
oluşturmakta, diğer yandan kabul edilen yeni bir sözleşmenin ilk uygulayıcıları olmaktadir.

UÇÖ’nün 102 Sayılı Sözleşme'nin bilinen sınıflandırmasıyla sosyal güvenliğin kapsadığı dokuz risk; tıbbi bakım, hastalık, analık, işsizlik, yaşlılık, iş kazaları, meslek hastalıkları, ölüm, sakatlık ve aile yardımları sosyal güvenliğin tanımlanmasının temeli olarak Avrupa Ekonomik Topluluğu (AET)'nun 1408/71 Sayılı Düzenleme Tüzüğü tarafından kullanılmıştır. Teknolojik dönüşüm ve hizmet sektöründe istihdam artışı sosyal risk yapılarında değişiklikleri uyarmakta ve toplumda kazanan ve kaybedenlerin olduğu bir olguyu yaratmaktadır. Geçmiş kapitalist dönemde standart üretim işçisi ve düşük nitelikli işçiler uygun ücret ve güvenceli iş edinme sağlanırken, bir yandan günümüzde bu durum olası olmamakta, diğer yandan iyi ve güvenceli yaşam için gerekli olan temel koşullar artmakta ve değişmektedir. Yetersiz yetkinlik ya da kültürel ve sosyal kaynağa sahip olanlar düşük ücret, işsizlik ve eğreti işlerle belirlenmiş bir yaşam sürecine doğru kayma yaşayabilmektedir (Esping-Andersen, 2002, s. 2; Langendonck \& Put, 24.08.2015, s. 4).

Sosyal güvenlik; tıbbi bakım da dahil olmak üzere insan onuruna uygun bir yaşam için her insana yeterli kaynakları sunmak; işçilere (bağl1-bağımsız çalışanlar) hastalık, kaza, analık, sakatlık ya da işsizlik nedeniyle kazançları kesintiye uğradığında ya da çalışma yaşamlarının son bulması nedeniyle gelirlerinin yerine yedek gelir sağlamaktadır. Öte yandan esneklik ve güvencenin bağdaştırılmasında sosyal güvenliğin başka bir özelliği ortaya çıkmaktadır, o da; bütün çalışmaya hazır işçilerin işgücü piyasasıyla bütünleşmesini sağlamak ve bütün vatandaşların sosyal bütünleşmesine katkı sağlamaktır. Bu anlamda, insana zarar verebilecek konuların önlenmesi, gerekirse düzeltilmesi ve maddi karşılığın sadece son çare olarak görüldüğü daha çağcıl sosyal güvenlik anlayışıdır (Langendonck \& Put, 24.08.2015, s. 6).

Refah devletinin toplum için yeknesak (uniform) müdahalelerden bireyselleşmiş refah devleti müdahalelerine dönüşümü, çağcıl refah devletlerinin oluşturulmasında 
temel meydan okuma alanıdır ve refah devletinin bireyselleşme sorunu işgücü piyasalarında temel sorunu oluşturmaktadır. Diğer bir deyişle, işgücü piyasasından dışlanmış ya da sosyal güvenlik sisteminin dışında kalmış bireylere çeşitli yardım ve hizmetlerin nasıl verileceği önemli bir sorundur. $A B$ refah devletleri yardım ve hizmetlerin yeniden organizasyonunu yerel düzeye indirerek aktif sosyal içermeyi bireylere sağlamaktadır. Reformlar kamu politikalarını daha aktif ve eşgüdümlenmiş hale getirerek asgari gelir koruma gibi sosyal politika programlarını yerel yetkinin tasarrufuna bırakmaktadır. Yerelleşmiş refah müdahale süreçleri, refah hizmetlerini sağlayan modelleri değiştirmiştir. Bu anlamda, yeni yönetişim teknikleri istihdam ve sosyal politika refah hizmetlerinin yeniden organizasyonunun yerel düzeye çekilmesini sağlamıştır (Hemerijck, 2015, s. 245; Künzel, 2012, s. 4).

Asgari sosyal koruma ya da sosyal koruma tabanı (the social protection floor), başta kırılgan kümeleri olmak üzere yaşam boyunca bireylerin güçlenmesi ve korunmasını önceleyen temel sosyal hizmetlere erişimi kapsayan ve gelir güvencesi sağlayan bir takım sosyal politikalar olarak tasarlanmaktadır. Sosyal koruma tabanı sosyal koruma sisteminin üç temel işlevini karşılamaktadır: Krizle yüzleşildiğinde gelirin ve tüketimin korunması; temel mal ve hizmetlere erişimin sağlanması; işgücü piyasalarının işleyişini geliştirilmesi için yetkinliklere ve insana yatırım yaparak gelir elde etme kapasitesinin artırılmasıdır. Sosyal koruma tabanı kısıtlı kaynak durumlarında bile uygun olan birtakım güvencelerin sağlanmasıdır. $\mathrm{Bu}$, herkes için bazı sosyal güvenceleri (yatay boyut) genişletme arayışıdır, ama aynı zamanda da yüksek standartlarda sosyal korumanın (dikey boyut) aşamalı olarak uygulandığı bir düzlem olarak tasarlanmıştır. Sosyal koruma tabanı kapsamlı ve güçlü sosyal koruma sisteminin kurulmasını amaçlayarak, tam gelişmiş sosyal güvenlik sistemi ile aşamalı olarak bütünleşmeyi sağlamaktadır.

\subsubsection{Güvenceli esneklik ve İşgücü Piyasasında Koruma}

Güvenceli esneklik özel ya da kamu eliyle işçiler ve işverenlerin eşgüdüm içinde daha çok ve daha iyi işler için politikalar içerir ve bu politikalar, sosyal dişlanma riskini azaltmak için işgücü piyasasının içindeki ve dışındaki işçilere güvence 
sağlamaya odaklanmıştır. Ayrıca, güvenceli esneklik işçilerin çalışma yaşamından emekliliğe, eğitim yaşamından işe, bir işten başka bir işe ve istihdam edilmeden işsizliğe geçişlerin yaşam boyunca desteklenmesi, yeteneklerin gelişimi ve daha iyi işlere ulaşmasıyla ilgilidir. $\mathrm{Bu}$ nedenle güvence, işçilerin işsiz kaldıklarında hızla yeni iş bulmasına yardımcı olan ve çalışma yaşamlarında gelişimlerini sağlayacak olan becerilerle donatılmasını içerir. $\mathrm{Bu}$ aynı zamanda yeni işlere geçişi kolaylaştıracak yeterli işsizlik yardımlarıyla da ilgilidir. Sonuç olarak, bu bütün işçilere özellikle de yaşlı ve düşük nitelikli işçiler gibi zayıf işçi kümelerine eğitim firsatlarını kapsamaktadır (Manca, Governatori, \& Mascherini, 2010, s. 6).

Güvenceli esneklik, işgücü piyasasında düşük düzeyde ücret alanların korunmasını gelir güvencesi ile birleştirmektedir (Kuivalainen \& Nelson, 2010, ss. 4-5). Bu anlamda güvenceli esneklik işgücü piyasalarının esnekleşmesini özellikle kırılgan kümelerin bazı sosyal faydalarla korunması ve sosyal güvenlik olanakları ile karşılanması düşüncesine dayanır (Zirra, 2012, s. 63). Bu nedenle güvenceli esneklik, sosyal güvenliğin yaygınlaştırılması ve istihdamın artırılmasındaki dengeleyici önlemleri getirerek, koşulsuz kuralsızlaştırmadan farklıdır. Bu etmenler arasında dengenin nasıl sağlanacağına ilişkin görüş birliği sadece belirli çevreler için değil hükümetler, işverenler ve işçi sendikaları arasındaki görüşmeler (toplu sözleşmelerdekine benzer) için de önemli bir konudur (Tangian, November 2009, s. 12).

Güvenceli esnekliğin temelinde, işgücü piyasasının içinde ve dışındaki kırılgan kümelerin korunması vardır. $\mathrm{Bu}$, güvenceli esneklik politika ve önlemlerinin özellikle işgücü piyasasındaki güçlü kümelerin güvencelerini (istihdam, gelir ve sosyal) artırma anlamına gelmemekte, işgücü piyasası esnekliğini sağlayan politika ve önlemler anlamına gelmektedir. Ancak, işgücü piyasasında zayıf ve güçlü sınıflandırmasının oldukça göreceli bir anlamı vardır ve her işgücü piyasasına ve ülkeye göre değişmektedir (Wilthagen \& Tros, 2004, s. 170). 


\subsection{Güvenceli Esneklik Bağlamında Kırılgan Kümelerin Sosyal İçerilmesi}

Güvenceli esneklik özellikle düşük koşullarda yaşayanların sosyal yardımlarla desteklenmesi ve esneklikle kuralsızlaşan işgücü piyasalarının insanileştirilmesidir. $\mathrm{Bu}$ tanımlama güvenceli esnekliğin sınırsız bir kuralsızlaştırmadan farkını, telafi edici sosyal güvenlik önlemleri ve istihdam artırıcı önlemleri getirdiğini vurgular. Güvenceli esneklik kuralsızlaştırmanın ve sosyal yardımların zamana bağlı yerine getirilmesine bağlıdır. Bu etmenlerin dengelenmesinde olası uzlaşma, hükümet, işçi sendikaları ve işverenler arasında toplu sözleşmelere benzer olarak yapılan görüşmelere dayanır (Pasnicu \& Ciuca, (15.04.2013), ss. 43-44).

$\mathrm{AB}$ ülkeleri işsizlik sigortasının yardım düzeyini ve süresini yeni kümeleri kapsayacak biçimde güçlendirmektedir. Aktif işgücü piyasası önlemleri mesleki eğitim ve iş deneyimi programları ve işe ilk başlama teşviklerini artırmaktadır. Kamu istihdam hizmetleri özellikle gençler, göçmenler, kısa süreli iş sözleşmesiyle işçiler, işten çıkarılanlar ya da herhangi bir gelir elde etmeyenler gibi kırılgan kümelere iş arama yardımını amaçlamaktadır ((EC.), 2010, s. 4).

Küreselleşmenin artırdığı işgücü piyasalarında katmanlaşmanın artması kırılgan kümelerin sosyal içermeye gereksinimleri sosyal koruma ya da sosyal güvenlik sistemleri ile sağlanmaya çalışılmaktadır. Kadınların işgücü piyasalarına içerilmesi çocuklara sağlanan sosyal yardımlar ve aile yardımları ile sağlanmaktadır. Gençlerin sosyal içermesini sağlayacak iki kurumsal düzenlemeden birisi eğitim iken diğer işgücü piyasasına girişlerinin sağlanmasıdır. Nüfusun yaşlanması ile birlikte sosyal güvenllik sistemlerinin yaşlılara sağladığı sosyal yardımların ve emeklilik ödemelerinin yerine ya da yanı sıra işgücü piyasalarına yeniden katılımlarının sağlanması temel amaçtır.

İşgücü piyasasının katmanlaşmasının nitelikli ve niteliksiz biçiminde katmanlaşması sonucunda, niteliksiz işçilerin nitelikli işçilere göre görece sık sık işsiz kalmaları ve işsizlik oranlarının toplam işgücü içinde önemli bir orana sahip olması sosyal içerme gereksinimini daha da artırmaktadır. 
$\mathrm{AB}$ ülkelerinde kırılgan kümeler içindeki göçmenler temel sorun alanını oluşturmaktadır. AB ülkelerinde görece diğer kırılgan kümelerde sosyal içerme için görece sosyal yardımlar ve hizmetler sağlansa da, bunlar göçmenlere daha az sağlanmaktadır. Aşağıda bu kümelere yönelik sosyal içerme ayrıntılı olarak incelenmektedir.

\subsubsection{Kadınlar ve Çocuklar}

$\mathrm{AB}$ ülkelerinde kadınlar işgücü piyasasına katılımının artmasına bağlı olarak çalışma süreleri artıkça boş zaman gerekinimleri de artmaktadır. Bu nedenle kadınlar bir yanda aile yükleri diğer yanda iş yükleri arasında bir bağdaştırmaya zorlanmaktadır. Atipik işlerde kısmi ve geçici süreli istihdam edilme kadınlara standart işlerde tam süreli çalışmaları yerine önerilmektedir.

Kadınların çalışma süreleri esnekliği ile özel yaşam ve işi birleştirmek ya da yeni deneyimler kazanmak, sosyal ağlarını genişletmek ve değişen tercihleri yerine getirmek için esnekliğe ilgi duyabilmekte ve bu nedenlerle esnekliği kabul etmektedir (Räisänen \& Schmid, 2008, s. 3). Öte yandan kadınlar hem ev işçisi hem ailenin geçim kaynağı durumuna gelerek ücretli ve ücretsiz iş arasında gidip gelmektedir. Bu nedenle kadınların işgücü piyasasında kendilerine iş ve boş zaman arasında bağdaştırmayı sağlayacak işlere gereksinimi artmaktadır (Fredman, 2004, ss. 300-301). Bu anlamda, işgücü piyasalarında özellikle kadınlar için çocuk bakımının iyi gelişmiş sistemi, çalışan ebeveynler için güvence yarattığından bağdaştırmayı sağlayan en önemli konudur. Böylece, işgücü piyasasında özellikle genç kadınların esnek işgücü sunumu gerçekleşebilecektir (Bonoli, 2010, s. 9; Madsen, 2006, s. 10). Ayrica kadınlar, tek ebeveynli ailelerin ve ikili kariyerlerin (dualcareer) artması sonucunda aile gereksinimlerini karşılayabilmek için tele çalışma gibi atipik istihdam biçimlerine yönlendirilmektedir (Golden, 2008, s. 361). Kadının işgücü piyasasına yüksek katılımını farklı düzeneklerle sağlayan Kuzey refah devletleri, sosyal koruma yoluyla kadının korunmasını işgücü piyasalarında sağlayabilmektedir. Kuzey refah devleti modelindeki ülkelerin nüfusun işgücü piyasasıyla bütünleşmesini sağlayan temel araçlara sahiptir. Bunlardan en önemlisi 
her iki cinsiyetin çalışma yaşamında ücretli çalışma saatlerinin miktarının yüksek olması, yine her iki cinsiyetin işgücü piyasasına erken giriş ve geç çıkışı, 1lımlı kısmi süreli istihdam oranları ve kapsamlı kısmi süreli istihdamlarıdır. Diğer refah devletleri modelleriyle karşılaştırıldığında Kuzey modelinde ücretli iş; cinsiyetler, aile üyeleri ve yaş grupları arasında görece eşit dağıtılmaktadır (Klammer, October 2006, s. 162-163; Vielle \& Walthery, 2003, s. 23-24).

Kuzey ya da İskandinav refah rejimine sahip AB üyesi ülkelerde özellikle İsveç, Danimarka, Finlandiya ve bir dereceye kadar Hollanda'da hem erkek hem de kadın işgücünün bütün çalışma yaşamı boyunca, işgücü piyasasına katılımı yüksektir. İsveç’te 15-64 yaş arasında bütün vatandaşların dörtte üçü istihdama katılmaktadır. $\mathrm{Bu}$, görece düşük işsizlik oranları anlamına gelmektedir. Gençlerin çoğu özellikle Hollanda ve Danimarka'da işgücü piyasasıyla bütünleştirilmiştir. İsveçli, Danimarkalı ve Finli çiftler arasında istihdama katılım yüksektir ve tek gelirli ailelerin oranı beşte birden azdır (Klammer, October 2006, s. 26-27).

Kadınlar kırılganlığın en yaygın olduğu kümedir. Kadınlar geleneksel olarak düşük nitelikli işlerde düşük ücret düzeylerinde atipik biçimde istihdam edilmekte ve günden güne istihdama katılımları da artmaktadır (T. Erdut, 2005, s. 34).

Lizbon stratejisi genel istihdama katılım oranının iyileştirilmesinin yanı sıra kadın istihdamının da iyileştirilmesini amaçlamaktadır. Bu anlamda Lizbon stratejisi AB üyesi ülkeler için istihdam hedefleri koymaktadır. Kadınların istihdama katılım oranları 15 AB üyesi ülkede 2000 yılında yüzde 54,1'den 2005 yılında yüzde 57,7’ye çıkmıştır. Böylece yüzde 57 olan ara hedefe ulaşılmıştır. Bu oran $27 \mathrm{AB}$ ülkesinde yüzde 53,7'den yüzde 56,2'ye artmıştır. İstihdama katılım oranı (İKO) 2006 yılında 15 üye ülkede yüzde 58,6'ya ve 27 AB ülkesinde yüzde 57,2'ye çıkmıştır. Bu oranlar Lizbon stratejisinin 2010 yılı için yüzde 60 hedefine yakındır. Hatta 2010 yılında kadın işgücünün İKO 27 AB ülkesinde yüzde 62,1 olarak gerçekleşmiş ve 2015 yılında bu oran yüzde 64,3 olarak gerçekleşmiştir. Bu anlamda kadınların İKO toplam İKO’na göre daha fazla artmış ve Lizbon Stratejisinin bu anlamda hedefini tutturmuştur. Kadınların istihdam biçimleri bakımından atipik 
istihdam biçimlerinde, erkeklere göre daha düşük ücret koşullarında eğreti işlerde istihdam edildiği düşünüldüğünde bu artışın nedeni ortaya çıkmaktadır. Üçüncü hedef 55 ve 64 yaş arasında belirlenen yaşı işçilerin İKO 2005 yılında kadın yaşlı işçiler için 15 üye ülkede yüzde 37,8'den yüzde 44,1'e ve 27 üye ülkede yüzde 36,9'dan yüzde 42,9'a yükselmiştir. 2006 y1lında yenilenen Lizbon stratejisinin etkisiyle 15 üye ülkede yüzde 45,3 ve 27 üye ülkede yüzde 43,5'e yükselmiştir (Dieckhoff \& Gallie, 2007, s. 485; Eurostat, 2007, s. 1; 2010, s. 13).

AB'de hem gelişmiş, hem de gelişmekte olan ülkelerde kadınların işgücü piyasasına katılımının artması cinsiyet eşitliğinin kadınlar lehine düzeldiği anlamına gelmemekte, aksine kadınların eşitsizliğinin boyutunu değiştirmektedir. Bu anlamda kadınların görece sosyal ve politik eşitsizliği giderilmiş olsa da düşük gelirli, eğreti ve sosyal güvenceden yoksun işlerde çalışması ekonomik cinsiyet eşitsizliğini artırmaktadır. $\mathrm{Bu}$ ekonomik eşitsizliğe, çekirdek aileden atomize olmuş aile yapılarına dönüşmesi eklendiğinde kadınların eşitsizliği erkeklere göre daha da derinleşmektedir (Z. Erdut, 2004, s. 22). Bu anlamda, kadınlar atipik istihdam türlerinden geçici ve belirli süreli iş sözleşmelerinde görece iş güvencesiz ve düşük gelirle, mesleki eğitime erişimden ve emeklilik planlarından dışlanmaktadır. Ayrıca, kadın ve erkek özel istihdam bürolarının geçici işlerinde birbirine yakın oranlarda istihdam edilmekte, ancak belirli süreli iş sözleşmeleri ile istihdam edilen kadınların oranı erkeklerin oranından daha fazladır (Fredman, 2004, s. 300-301).

\subsubsection{Gençler}

Gençlerin işgücü piyasasına katılımı sosyal bütünleşmelerinin temelidir. Bu nedenle başta genç işsizler olmak üzere tüm işsiz insanların üretimsel bilgisini ve işgücü hizmetlerini sunmalarının engellenmesi, sosyal dışlanmanın temel kanallarından biridir. Genç işsizlik oranı toplam işsizlik rakamlarının iki katıdır. Uzun dönem işsizlerin çoğunluğunu oluşturan gençler, istihdam edilebilirliklerini sağlamak için işgücü piyasası programlarından birine katıldıktan sonra bile dışlanmaktadır. $\mathrm{Bu}$ anlamda, gençlere kapasitelerini, becerilerini ve yaratıcılıklarını göstermek için 
herhangi bir şans verilmemesi, bunların en iyi olasılıkla isyancı ve apolitik ya da en kötüsü suçlu olmalarına neden olacaktır (Schmid, 1998, s. 1).

AB'de işsizler içinde büyük orandaki genç işsizlerin sayısını azaltmak için yedi yıllık "Avrupa Gençlik Güvence Programı" kapsamında altı milyar Avro sağlanmıştır. Öte yandan UÇÖ Avro Bölgesinde gençlere etkin güvence sağlamak için asgari 21 milyar Avroluk bir maliyet öngörmektedir. Öte yandan, Dublin'deki Eurofound (İş ve Yaşam Koşullarını Geliştirme Vakfi) Avro bölgesindeki yedi buçuk milyon genç işsiz için psikolojik ve diğer maddi maliyetler dişında 150 milyar Avroluk bir maliyet öngörmektedir (Schmid, May 2014, s. 15-16).

Almanya ve Fransa' da eğitim bir iş elde etme olasılığını belirlemede önemli bir yere sahiptir. Çelişkili olarak, gençler arasında eğitimsel kazanımların artan düzeyi ile birlikte işgücü piyasalarının bozulması, eğitimin niteliğinde değer kaybına ve yüksek eğitimliler arasında işsizlik oranlarının artmasına yol açmaktadır (Campbell et al., 2011, s. 12). Ancak buna karşılık, AB'nin gelişmiş ülkelerinde özellikle Batı Avrupa ülkeleri nitelikli ve beceriye sahip işgücü gereksinmesini karş1layabilmek için göçmen politikalarını oluşturmuştur. Örneğin Almanya'da 2007 yılında işsizlik oranı yaklaşık yüzde 10 iken bile, belirgin nitelikli işgücü açığı vardır. Özellikle bu sorun sağl1k, kurumsal yönetim, mühendislik (özellikle bilgi ve iletişim teknolojileri -BİT) ve diğer teknik mesleklerde vardır. Sosyal taraflar ve hükümet; göçmen yasalarının yeniden gözden geçirilmesi ve yumuşatılması ve emeklilik yaşının yükseltilmesi gibi işletmelerin dışında çözüm bulmak için yoğun çaba göstermiştir (Torka \& Velzen, 2008, s. 96).

\subsubsection{Yaşlılar}

Yaşlı işçilerin istihdam edilebilmelerinin sağlanması için, çalışma durumunda yaşlı işçiye mali katkı ve aynı zamanda emeklilik ve erken emeklilik sistemlerinde caydırıcılık öngörülmektedir. Pek çok ülke yaşı işçilere mesleki kariyerleri sürdürmeleri durumunda yüksek emeklilik ödülleri sağlamayı ve aynı zamanda işe dönmeleri durumunda caydırıcılıkları önlemeyi amaçlayan emeklilik reformları 
gerçekleştirmektedir. Ayrıcalıklı erken emeklilik planlarına yeni girişleri sona erdirmek için genel bir eğilim vardır. İş arama gerekliliklerinin dışında tutulan belirli bir yaşın üstündeki işsizler işsizlik yardım sistemleri yoluyla ya da kötü tasarlanmış hastalık ve sakatlık yardımları yoluyla erken emeklilik kapsamına alınmaları pek çok ülkede sınırlandırılmaktadır. Ancak bu reformlara rağmen yeni liberal görüşe göre; kamu emeklilik sistemlerinin tasarımı ve fiili erken emeklilik sistemleri hala çoğu ülkede işgücü piyasasından erken çekilmeyi içeren teşvik çarpıklığını barındırmaktadır. Ayrıca, özel mesleki emeklilik sistemleri katılımcılara görece erken yaşta emekliliği teşvik etmektedir. Yaşlı işçiler için istihdam olanakları zorunlu emeklilik uygulamaları, kıdeme bağlı ücretin geniş kullanımı ve eğitim olanakları işletmelerde yaşlanma nedeniyle durdurulmaktadır (OECD, 2006, s. 15).

\subsection{4. İşsizler}

AB'de doksanlı yıllardan itibaren işsizlik giderek azalmasına karşın, yine de yüksektir ve üye ülkeler arasında düzensiz biçimde dağılmaktadır. Ayrıca, işsizliğin ortalama süresi artarak, toplam işsizler içinde uzun dönem işsizlerin oranı artmıştır. $\mathrm{Bu}$ yapısal değişim alışık olunmayan bir sosyal süreci de beraberinde getirmiştir ve böylece, uzun dönem işsizlikle yüzleşen işçiler diğer işçilere göre kısa süreli sözleşme önerilerini kabul etmektedir (Tangian, October 2004, s. 9). Öte yandan, 2007 yılında AB'de yaklaşık 17 milyon işsiz vardır, nüfusun yüzde 16'sı yoksulluk tehdidi altındayken, işletmelerin gereksinmelerine uyum sağlama koşuluna bağlı olarak da bir milyon açık iş vardır. Ayrıca, AB'nin ana rakipleriyle karşılaştırıldığında, işçi başına ve çalışılan saat başına verimlilik açısından önemli açıkları vardır. $\mathrm{Bu}$ bakış açısı dikkate alındığında, $\mathrm{AB}$ 'de yüzde 70 istihdam oranı ile ilgili olarak ekonomik durgunluk sorununu çözmek için yeniden düşünülmelidir (Pasnicu \& Ciuca, (15.04.2013), s. 40).

Belçika'da işverenler işçileri işten çıkarmak istediğinde çıkarma sebebinin haklı (adil) olması ve işçiye yeterli bir süre önce bildirmesi gerekir. Bildirim süresine uyulmayacaksa işveren işçisine çalışacağı durumda tazminat niteliğinde ödeyeceği ücreti öder. Bu durum Belçika'da kıdem tazminatı ödeme sistemini de beraberinde 
getirir. İhbar süresi beyaz yakalı işçilerde mavi yakalılara göre daha yüksektir. Bildirim süresi iş sözleşmelerinin belirli süreli ya da belirsiz süreli türüne ve işçilerin deneme süreleriyle çalışıp çalışmayacakları durumlarına göre bir iş kolunda toplu pazarlığa göre değişir. Toplu sözleşmelerde işçileri işverenlerin eş zamanlı kümeler halinde çıkarmasına ilişkin bir toplu işten çıkarma özel usulü varsa o uygulanır. Usul süreleri karmaşıktır. İşverenler işçileri, işçi sendikalarını ve bölgesel kamu istihdam hizmetleri kurumunu sürelerinde bilgilendirmesi gerekir. Bu durum işten çıkarmanın adil olması gerektiğini gösterir. İşçi sendikaları işten çıkarma konusunda seçenekleri gündeme taşıması gerekmekte, ancak işçi sendikası ve işverenin uzlaşması gerekmemektedir. İşçilerin bazı kümeleri hariç, işten çıkarma durumunda kıdem tazminatı daha yüksektir. Ayrıca, işletmeler yeniden işe yerleştirme hizmetlerinin mali yükünü karşılamaktadır (Bart \& Linden, 2009, s. 5).

Belçika'da işsizlik sigortası geçici işsizlik sigortası ve genel işsizlik sigortası olmak üzere iki türlü sağlanmaktadır. Sadece mavi yakalı işçiler geçici işsizlik sigortası planlarına erişebilmekte ancak işverenler beyaz yakalı işçiler için de genişletilmesini istemektedir. Bu durum işletmelere kıdem tazminatı ödemeden işçileri geçici olarak işten çıkarma sağlamakta, ancak iş sözleşmesi sürmektedir. İşçiler yeniden işbaşı yapana kadar işsizlik yardımlarından sabit bir seviyede yararlanabilmektedir. İşsizlik yardımlarının türü ve düzeyi hanehalkı içinde işsiz kalan işçinin durumuna bağlıdır (aile reisi, aile reisine bağlı ya da tek ebeveyn). Yeniden değerleme oranı (çalışırken elde ettiği ücrete göre aylı bağlama oranı) ortalama yüzde 68 ile uluslararası standartlara göre düşük iken komşu ülkelerde ortalama yüzde 73'tür. Aile reisi, süresiz olarak aynı düzeyde işsizlik yardımlarından yararlanmaktadır. Tek ebeveynli ailelerin ve aile reisine bağımlıların işsizlikten yararlanma süreleri azaltılmakta, yine de sabit bir oranla sınırlandırılmaktadır. 2004 yılından itibaren uzun dönem işsizlerin iş arama çabasına ilişkin bir değişikliğe gidilmiş, iş aramada yeterli çaba göstermeyen işçiler işsizlik yardımlarını kaybetmektedir. İşsizlik yardımları federal düzeyde sağlanmaktadır. İşsizlik yardımlarının malileştirilmesi brüt ücret üzerinden yapılan katkılarla sağlanmaktadır. Aktif işgücü piyasası politikası (AİPP) genel olarak federal bölgeler tarafindan sağlanmaktadır. 
1990’lı yıllarda bazı değişikler yapılmasına rağmen, Avrupa ülkeleri arasında işsizlik yardımlarını alma süresi bakımından farklılıklar vardır. AB'de en uzun süreli işsizlik yardımları Danimarka (dört yıl) ve Belçika (sınırsız)'dadır. Belçika'da işsizlik yardım süresi Danimarka'dan uzun olsa da işsizlik yardımlarının yeniden değerleme oranı düşüktür. Danimarka işsizlik yardımında yeniden değerleme oranı işsizlik öncesi ücretin yüzde doksanıdır. Bu nedenle Danimarka'da düşük ücretlilerin işsiz kalma riski daha fazla iken, işe girme eğilimi daha fazladır. Aynı zamanda son yıl boyunca tam zamanlı ve sürekli çalışan işçiler için yeniden değerleme oranları çok az da olsa azaltılmıştır (Eriksson, 2012, s. 13; Klammer, October 2006, s. 158; Vandenberg, September 2010).

Ancak, Danimarka'da işgücü piyasası reformlarının çoğu, işsizlik yardımlarının uzun süresini kısıtlamaya ve kullanılabilirliğini artırmaya odaklanmaktadır. Bu reformlar eğitimlerle iş arama süresini kısaltma ve işsizlere rehberlik hizmeti sağlama amacındadır. Her üç ayda bir Danimarka istihdam hizmetleri ile bağlantısını sürdüren ve programlara katılan işsizler işsizlik yardımlarından yararlanabilmektedir. İşsizliğin ilk yılında her işsiz için eylem planı hazırlamak zorunluluktur. İlk yıldan sonra işgücü piyasasının dışında kalan her işçi bir tür aktivasyon programına katılmak zorundadır (Jensen \& Larsen, September 2005, s. 62).

AİPP, işgücü piyasasında işsizlerin becerilerini güncellemek ve işsizlerin iş aramaları ve aktif kalmalarını sağlamak gibi çift yönlü amaca sahiptir (Jensen \& Larsen, September 2005, s. 56). Danimarka AİPP'lerine ve işsizlik yardımlarına diğer $\mathrm{AB}$ üyesi ve OECD üyesi ülkelerden daha fazla harcama yapmaktadır. Buna rağmen yaşlıların (60-65 yaş arası) istihdama katılım oranı düşüktür (Jensen \& Larsen, September 2005, ss. 56-65).

Pasif işgücü piyasası politikası işsizlik durumunda yardım alma koşullarıdır. $\mathrm{Bu}$ pasif önlemler gelirin sürdürülmesi için kamu desteğini kapsar. Bu nedenle, işsizlik sigortası sistemi işsizlere en iyi işi bulmak için olanaklar verir. Diğer yandan, pasif önlemlerin işsizlerin işe girmek için gerekli isteği azalttığ1 da ileri sürülmektedir. $\mathrm{Bu}$ anlamda görece cömert işsizlik yardımlarını uzun süre alan işsizler bütçeye yük 
oluşturmaktadır. Ancak, işsizlik yardımlarının en önemli işlevi işsizlerin yoksulluğa düşmeden işgücü piyasasında kendi yetkinlikleriyle en uygun eşleşen işi bulabilmek için uzun iş arama olanağ 1 vermesidir.

Danimarka'da işgücünün yüzde 75'inden fazlası işsizlik sigortası kapsamındadır, kapsam dışında kalanlar ise düşük oranlarda da olsa sosyal yardımlardan faydalanmaktadır. Danimarka esnek işgücü piyasasının temel özelliklerinden birisi kısa dönemde cömert işsizlik yardımları sağlamasıdır. Bu, işverenlerin işçileri görece kolay ve maliyetsiz işten çıkarmasını ve işçilerin kolay ve maliyetsiz iş bulmasını sağlamaktadır. İşsizlik sigortasının karşılama düzeyinin yüksekliği kendilerini güvenceli hisseden işçilerin yeni ve belki daha iyi bir iş bulmaları için işlerini birakabilmektedir (Jensen \& Larsen, September 2005, s. 61).

Etkili bir sosyal güvenlik ağ 1 işsizlerin gelir kesintisi nedeniyle evlerini terk etmesini engellemektedir. Danimarka aktif işgücü piyasası politikası işsizlere eski işlerinden ayrılmalarında yeni işler için yeniden eğitim almaları olanağını sağlamaktadır. Güvence ağ1 Danimarka güvenceli esneklik modelinin bir parçasıdır. İşçilerin işten çıkma ve işe girmelerini kolaylaştırmada işgücü piyasasıyla önemli kamu yararı gözetilmektedir. İşçiler güvenceye sahip olacaklar, işverenler ise eylem özgürlüğüne sahip olacaklardır ( (KL), (02.05.2013), s. 5).

Düşük ücretler ve sendikasızlaşma kırılgan kümedeki işgücünü tanımlamada önemli ölçütlerdir. İşçi sendikaları, üyelerinin iş ve yaşam koşullarını iyileştirmekte ve çıkarlarını korumaktadır. Sendikasız işçiler bu istemlerden ve korumadan yoksundur. Sendikasız işçilerin hepsinin kırılgan olduğu söylenemez, ancak işgücü piyasasında koşulları farklılaştıran başlıca güç temsil güvencesidir. Özellikle, hem düşük nitelikli işlerde çalışan, hem de işçi sendikalarının temsilinden yoksun olan işçilerin ekonomik ve sosyal kazançları da düşüktür. $\mathrm{Bu}$ nedenle düşük ücret kırılganlık göstergesi olabilmektedir. Son 30 yıldır işgücü piyasasının yapısındaki değişiklikler kötü işlerde düşük ücretlerle çalışan kırılgan işçilerin hem oranında hem de sayısında artışla birlikte işlerin kutuplaşmasını getirmiştir (Pollert \& Charlwood, 2009, s. 344). 


\subsubsection{Göçmenler}

OECD üyesi Avrupa ülkelerinde yabancı işçilerin sürekli işlerde istihdamı son derece azdır. Özellikle göçmenlerin geçici işlerde çalışmasının yaygınlaşması işgücü piyasasında esnekliği artıran nedenlerden biridir. Yabancılar arasında uzun dönem işsizlik yaygındır ve sürekli işlere geçiş olanakları görece zayıftır (Tangian, October 2004, s. 10).

Ayrıca, yasadışı göçle gelen göçmen işçiler ve istihdam statüsünün dışında kalan işçiler iş yasasının korunmasından yoksundur ve bu işçiler arasında kırılganlık son derece yaygındır. Herhangi bir istihdam statüsü olmayan işçiler ücretsiz iş (aile ya da ev işçisi) ve ücretli iş baskın olarak özellikle kırılgan özellikler taşır, çünkü bu işçiler genelde geçici, gündelik, belirli süreli gibi standart dışı işlere sahiptir. Ayrıca, anılan işçiler istihdam koruma mevzuatı (IKM) ve istihdam sözleşmelerinin dışında kalarak yarg1 korumasından yoksundur. $\mathrm{Bu}$ düşük ücretli işçiler, ulusal sosyal sigorta katkıları (özellikle kısmi süreli çalışan kadınlar) için gerekli eşiğin altında kazanç elde ederek, zorunlu hastalık ve analık ödeneği gibi çalışamama durumunda elde edilecek sosyal yardımların dışına itilmektedir. Böylece, düşük ücret, standart dışı ücret, sendikasız işçiler en kırılgan küme olarak toplu sözleşme, istihdam koruma hakları ve ulusal sosyal sigorta düzenleme rejimlerinin hepsinin dışında kalmaktadır (Pollert \& Charlwood, 2009, ss. 344-345; Van Ginneken, 2013, ss. 210, 212).

AB'ye üye ülkelerdeki işgücü hareketi durumu iç göç olarak değerlendirildiğinde, Avrupa Topluluğu (AT) Antlaşması'nın 39. md'si işçiye diğer üye ülkede iş arama, istihdam ve çalışma koşullarına erişim konusunda eşit sözleşme sağlamanın yanı sıra, yine o üye ülkede kalmak ve yaşamak için hak sağlamaktadır. Öte yandan, gelişmekte olan ülkelerden oldukça nitelikli ve iyi eğitimli vatandaşların göçü küçük ve korunmuş ülkelerde ve yeni üye ülkelerde başta sağlık olmak üzere belirli alanlarda büyük sorun oluşturmaktadır (Kawinski \& Stanko, 2007, s. 3).

Bales, günümüzde işverenlerin eğreti koşullarda çalışan işçilere sosyal üretimleri için gerekli ücreti ve çalışma koşullarını sağlayamadığını vurgulamıştır. Ayrıca, işçi sadece bir sonraki gün için çalışabilecek ya da yaşamda kalabilecek gıdaya karşılık 
gelecek düşüklükte bir ücretle, işveren tarafindan çalıştırılmaktadır. Tarım ve sanayi üretimi için kölelik döneminde köleleri üretim aracı gibi yüksek tutarlarda satın alarak kullanan köle sahipleri kölelerine ve onların ailesine gıda, giyinme ve barınma sağlarken, günümüzde işverenler ise yeni düzenle birlikte işçilere yüklü tutarlar ödemeksizin sadece günlük düşük ücret ile çalıştırmaktadırlar (Bales, 2002, s. 21). Günümüzde Londra gibi Avrupa'nın büyük şehirlerinde göçmen ve düşük ücretli işgücüne dayanan bir ekonomik politika çerçevesi oluşmuştur. $\mathrm{Bu}$ şehirler düşük ücretli temizlikçi, bakıcı, inşaatçı, aşçı, barmen ve lokanta hizmetleri işçilerinin emek gücüne bağımlı hale gelmiştir. Bu bağlamda, yeni liberal politikalar ve küreselleşme arasında diyalektik etkileşim sonucunda göçmen işçiler, bir yandan uluslararası sınırlar ötesine geçerek çalışma isteği oluşturulmakta, diğer yandan bu göçmen işgücünün yeniden üretimi (sosyal yeniden üretim) yok edilmektedir. Eğreti koşullarda çalıştırılan göçmen işçiler seçim olanaklarının azlığı ve sosyal korumanın dışında kalmaları nedeniyle düşük ücret ve uzun çalışma süreleri ile zor işlerde çalışmaktadır (Lewis, Dwyer, Hodkinson, \& Waite, 2014, s. 4; Munck, 2013, s. 747748). Bu anlamda göçmen işçiler dünyada bitmeyen eşitsizlik, düzensizlik ve adaletsizlik tarihinin getirdiği yeni kölelerdir.

\section{4. Üye Ülkelerde Kırılgan Kümelere Sağlanan Sosyal Yardım ve Hizmetler}

\section{1. Üye Ülkelerde Sosyal Yardım ve Hizmetleri}

\subsubsection{Sosyal Yardım ve Hizmetlerde Dönüşüm}

Öte yandan gelişmiş ülkelerde yeni liberal idelojiler sonucunda yaşl1lar ve çocuklar için bakımda sosyal yatırım eksikliği ve refah bütçelerinin azaltılmasıyla ailelerin bu hizmeti kamu hizmetleri yerine piyasadan karşılamaları enformelleşmeyi artırmaktadır. Diğer yandan nüfusun yaşlanması ve kadınların giderek daha fazla işgücü piyasasına katılmaları ulusötesi kadın göçmenliğini artırmaktadır. Gelişmiş ülkelerin işgücü piyasalarında kayıtlı ve görece uygun işlerde istihdam edilen kadınlar, temizlik, yemek, yaşlı bakımı, çocuk bakımı gibi evsel işleri yoksul ülkelerin göçmen işçi kadınlarını eğreti koşullarda düşük ücretlerle kayıtdışı biçimde 
çalıştırmaktadır. $\mathrm{Bu}$ anlamda, kadınların işgücü piyasasına katılımının artması küresel bakım tedarik zinciri oluşturmuşstur. Gelişmiş ülkelerin vatandaşı olan kadın işgücü piyasasına katıldığında, anılan hizmetleri daha ucuza gelişmekte olan ya da gelişmemiş ülkeden göçmen kadın işçiye bırakmakta, göçmen kadın da kendi yaşlı ya da çocuğunu bir başka kadının bakımına bırakmaktadır. Böylece, kadının küresel ekonomide bakım tedarik zinciri üzerinden metalaşması artırılmaktadır (Hobson \& Bede, 2015, ss. 328-330).

Yetmişli yılların sonundan itibaren OECD’nin politika tavsiyesi yeni liberal özellik taşımaktadır. Bu yeni liberal politikalar OECD’nin İş Stratejisi yoluyla sürüdürülmüş ve bu AB'nin tutumunu dönüştürmüştür. Hem OECD hem de AB Kuzey ülkelerine daha fazla verimlilikte ve tercihinde piyasa merkezli çözümleri kabul etmesi için bakılarını artırmaktadır. Aynı zamanda OECD’nin İstihdam, Çalışma ve Sosyal İşler Müdürlügü sosyal yatırım paradigması olarak görülen formülünü başlattı. Sosyal yatırım paradigması, pasif önlemlerden tüketim odaklı aktif bir yönelime kaymasının gerekli olduğunu vurgulamaktadır. Bilimsel çalışmalara dayanarak erken çocukluk dönemine yapılan yatırımların, yetişkin eğitimine yapılan yatırımlara göre faydamaliyet oranının daha yüksek olduğunu göstermektedir. Bu durum çocuk bakımının yaygın desteklenmesinin önemini vurgulamaktadır. İsveç ve Finlandiya'da devlet yeni sosyal sorumlulukları karşılamaya teşvik edilmekte, böylece bu ilkeler meydan okumalara farklı yollardan yanitlar verebilmektedir (Mahon et al., 2012, s. 423).

Kuzey sosyal demokrat bakım rejimi belirli tarihsel gelişimlere bağlıdır. İlk olarak, evrensellik bütün vatandaşlara sosyal yardım ve hizmetlere erişimi sağlamaktadır. Evrensellik politikaları Kuzey ülkelerinde özellikle kadınlar için önemlidir ve bu bağlamda cinsiyet eşitliği desteklenmektedir. Kuzey rejimlerinin ikinci özelliği devletin merkezi rol oynamasıdır: Kamu iradesi, vergilendirme yoluyla sosyal yardım ve hizmetlere mali desteğin sağlanmasından sorumlu olmasıdır. Üçüncü özellik, sosyal demokrat partiler ve işçi sendikaları sosyal politikaların gelişmesinde itici güç olmasıdır (Mahon et al., 2012, s. 421). 


\subsection{2. Üye Ülkeler Arasında Yardım ve Bakım Hizmetlerinde}

\section{Iraksamalar ve Yakınsamalar}

Avrupa ülkelerinin ayrışık yapısı, özellikle refah devleti, endüstri ilişkileri sistemleri, işgücü piyasası düzenlemeleri ve pozitif bütünleşmenin diğer düzenleme alanlarına ilişkin kurumsal özellikleri, gelenekleri ve ilgileri açısından önemli bir role sahiptir. $\mathrm{Bu}$ bağlamda, ulusal egemenliğin korunması gerektiği yönündeki görüşün ağırlık kazanmasına olanak sağlayan bu ayrışık yapı, pozitif entegrasyon unsurları üzerinde bir anlaşmaya varılmasını da güçleştirmektedir. Ayrışıklık, 2004 ve 2007 yılları arasındaki, üye sayısını ve çeşitliliği önemli ölçüde arttıran, genişleme döneminde iyice belirginleşmiş ve bundan sonra pozitif bütünleşmenin gelişimi de içinden çıkılmaz bir hal almıştır (Keune, 2008, s. 93).

$\mathrm{AB}$ ülkeleri arasında yakınsama baskısı sadece ekonomik bütünleşmeden kaynaklanmamakta, aynı zamanda uluslararası kuruluşların rolü ve ulusötesi politika ağlarında yaygınlaştırılmasında artan hızdan kaynaklanmaktadır (Mahon et al., 2012, s. 423).

Avrupa 2020 ekonomik, sosyal ve istihdam politikaları alanlarında bütünleștirme sağlama amacını taşırken, AB’ye yetkinlik kazandıracak farklı eşgüdüm yöntemleri arasında kendine ters düşecek biçimde düzenleme yapmaktadır. Açıkça söylenirse, bir yandan kamu harcamalarında kısıtlamaya gidilmesi ya da kemer sıkılmasına ilişkin emeklilik politikası önemli bir konu olarak görülürken, diğer yandan yaşlı yoksulluğu ile mücadele edilmesi de önemli bir konu olmaktadır. Bu açıdan bakıldığında Avrupa 2020'nin hedefleri arasında politika belirsizliği vardır (Bekker, January 2013, ss. 2-3).

\section{2. Üye Ülkelerde Sağlanan Yardım ve Hizmetler}

\subsection{1. Üye Ülkelerde Sosyal Yardımlar}

OECD’ye göre kadınlar vergi olumsuzlukları, aile destek politikalarının kötü tasarlanması ve kısmi süreli işlerin eksikliğinden dolayı engellerle karşılaşmaktadır. 
İkincil işçilerin vergi işlemleri çoğu ülkede kadın işgücünün istihdama katılımını bastırma eğilimindedir. Aynı zamanda çalışma ile aile sorumluluklarını "bağdaştırmaya" yardımcı olabilecek uygun ebeveyn izni hükümlerinin eksikliği de kadın işgücünün katılımını azaltmaktadır. Ayrıca, çocuk bakım maliyetlerinin yüksek olması kadının evin dışında bir iş aramasını olanaksız duruma getirmektedir. $\mathrm{Bu}$ maliyetler genel çocuk yardımlarını çocuk bakım desteğine çevrilerek düşürülebilir. Ancak burada, çocuk yardımlarının aile yardımları gibi sosyal konuları çocuk bakım sübvansiyonlarından daha kolay hedeflemesi gibi bir politik ikilem vardır. Yani çocuk yardımları çocuk bakım yardımlarına göre daha sosyal kapsayıcılığ́1 olan bir konudur (OECD, 2006, s. 15).

İngiltere ve İrlanda gibi liberal refah devletleri işgücü piyasasında esnekliği karşılayacak yeterli güvence düzeyleri ve güvence mekanizmalarına sahip değildir. Öte yandan İsveç, Danimarka, Finlandiya gibi Kuzey ülkeleri ve görece Almanya, Avusturya, Belçika, Fransa gibi Korporatist refah devletleri ve hem Kuzey ülkeleri hem de korporatist refah devleti özelliği gösteren Hollanda'da kadınların işgücü piyasasına hem standart istihdam biçimlerinde katılmalarını hem de atipik istihdam biçimlerinde katılmalarını destekleyecek sosyal güvenlik mekanizmaları vardır. Ayrıca, esnek işgücü piyasalarına atipik biçimlerde katılan kadınların esnekliği karşılayacak güvence düzeyleri ve mekanizmaları vardır. Bu anlamda, liberal refah devletlerinde kadınların esnek işgücü piyasalarına katılımını karşılayacak güvence düzeylerinin düşüklüğü nedeniyle, görece işgücü piyasasında esneklik ve güvencenin bağdaştırılması da düşük düzeyde olmaktadır. Buna karşılık Hollanda gibi karma refah devleti ve Kuzey refah devletlerinde kadınların esneklik ve güvenceyi bağdaştırılma düzeyi yüksektir (Fredman, 2004, ss. 300-301; Klammer, October 2006, ss. 162-163; Vielle \& Walthery, 2003, ss. 23-24).

Ülkelerin sosyal güvenlik sistemlerince sağlanan sosyal yardımların toplumun geneline sağladığı koruma düzeyinin ne kadar etkin ve toplumu kapsayıp kapsamadığı konusu; ailenin korunması bağlamında çocukların yoksullukla yüzleşmesinin ne kadar az olup olmadığı ile ilgilidir. Bu anlamda sosyal güvenlik sistemlerindeki ve ücret, eğitim, vergi gibi diğer korumaya bağlı sistemlerdeki 
gösterdikleri başarının yanı sıra, gelir-bölüşüm ilişkisindeki başarı ülkeden ülkeye çeşitlilik göstermektedir. Çocuk yoksulluğu $\mathrm{AB}$ ülkelerinde ve dünyada en düşük İsveç’tedir. Kuzey refah devletlerinde çocuk yoksulluğunda diğer AB üyesi ülkelerden ve diğer ülkelerden görece daha iyi durumdadır. Refah devleti olarak kabul edilen ABD'de toplam çocuklar içinde çocuk yoksulların oranı yüzde 19 ile Almanya'nın iki katı, İsveç'in beş katıdır. $\mathrm{Bu}$ durumun temel nedeni gelir dağılımındaki eşitsizliktir. Buna göre, Gini katsayısı İskandinavya'da 0,15, Almanya'da 0,30 ve Kanada'da 0,20 ve ABD'de en iyimser tahminle 0,46'dir (Esping-Andersen, 2007, ss. 23-24).

$\mathrm{AB}$ ülkelerinde ailelerin korunması çocukların durumu üzerinden değerlendirmeler sonucunda yapılmaktadır. Bu anlamda ailelerin korunmasındaki amaç, çocukların korunmasıdır (Harris, 2013, s. 113). Bu anlamda gelişmiş AB ülkelerinde cömert sosyal güvenlik sistemlerinde yüksek kalitede çocuk bakımına düşük maliyetle erişimin sağlanması aileler arasında gelir eşitsizliği ve istihdam eşitsizliğini azaltmakta ve çocuklar arasında eğitim boşluğunu daraltmaktadır. Bu politikayı gerçekleştirmek ülkeler için maliyetli olmaktadır. Örneğin İskandinav ülkelerinde gayri safi milli hasıla (GSMH)'nin yüzde bir ve ikisi arasında bir bütçe ayırarak yüksek nitelikte çocuk bakımına evrensel girişi sağlamak için çeşitli kuruluşlarla bir program gerçekleştirmektedir. Bu durum ilk bakışta ekonomiyi engelleyici olarak görünebilir, ancak yoksulluğun makro ekonomik maliyetinin daha yüksek GSMH'nin yüzde dördü- olduğu düşünüldüğünde, daha çok tercih edilebilmektedir. Ayrıca, günümüzde bu maliyetleri karşılayabiliyorken, toplumun hızla yaşlandığı düşünüldüğünde, gelecekteki işçilere bu yatırımların yapılmasından daha doğru bir durum yoktur (Esping-Andersen, 2007, s. 27).

\subsection{2. Üye Ülkelerde Bakım Hizmetleri}

Bakım yardımı ve hizmetlerinde bütün farkl1lıklar ülkelerin sahip olduğu refah devleti modellerinden kaynaklanmaktadır. Öte yandan, özellikle küçük çocukların bakımı ve yaşlıların bakımı sıklıkla bir refah devleti modelinde hatta bir ülkede farklı yollar izlenebilmektedir (Mahon et al., 2012, ss. 421-422). 


\subsubsection{Yaşlı Bakımı}

Yaşılların bakımı ülkelerin gelenek, görenek, refah düzeyi, yaşlılara bakış açısı, aile yapıs1, feodal, monarşik ya da demokratik yönetim rejimi gibi değişkenlere bağ $l_{1}$ olarak ekonomik, kültürel, politik ve toplumsal yapılara göre farklılılaşmaktadır.

Nüfusun yaşlanması işgücü ve refah devletinin maliyetinin karşılanması üzerine baskı yapmaktadır. Öte yandan, işgücü piyasasına katılanların giderek azalması çocuklar ve yaşlılar gibi aktif olmayan geniş kümelerin desteklenmesini azaltacaktır. Danimarka'da 15-65 yaş arasında nüfusun çeyreğine denk gelen 900 bin kişi kamu tarafından sağlanan yardım ve hizmetlerden yararlanmaktadır. Bu kümedekilerin çoğu sağlık sorunları gibi sebeplerle tam süreli çalışamamaktadır (Jensen \& Larsen, September 2005, ss. 64-65).

İki ebeveynli aileler yaşlı bakımı ve çocuk bakımı için çoğunlukla kesinti yaşamaktadır. Özellikle yüksek gelir kümesinde yer alan aileler (gelirden en yüksek payı alan yüzde 25) bu bakım hizmetlerini bir merkezle sağlanan hizmetler yerine bakıcı istihdam etmektedir. Çocuk bakımı İsveç ve Finlandiya'da piyasalaşma derecesi bağlamında ailelere (annelere) küçük çocuklar için bakım sağlanmaktadır (Mahon et al., 2012, s. 427).

Refah devletlerinin en önemli işlevi vatandaşlarının var olan ve gelecekte ortaya çıkabilecek yeni sosyal riskleri ya da bu sosyal risklerin toplum için sorun olabilecek sonuçlarını karşılayabilecek güvence önlemleri almalarıdır. Almanya'da iş kazası ve meslek hastalığı, işsizlik, hastalık ve emeklilik gibi risklere karşı güvence düzeneklerini yüz yıl öncelerine dayanmaktadır. Öte yandan, nüfusun yaşlanması, aile yapısında değişmeler gibi toplumsal dinamikler sonucunda 1995 yılında bakım sigortasını kurmuşlardır (Çağlar, 2015, s. 70). Bu toplumsal gereksinimler sonucunda oluşan bakım sigortası oluşturmanın temel gerekçesi ekonomiktir. Bu anlamda, Almanya gelecekte yaşlı nüfusun gereksinimlerini karşılayacak akçelendirmeyi şimdiden kuşaklararası ve kuşak içi dağıtım yöntemi ile çözmek istemektedir. 
Bakım gereksinimi olan yaşlılara gün içinde belli zaman dilimlerinde bakım gereksinimini gündüz bakım evlerinde sağlanmaktadır. Bu hizmet daha çok yaşlı bireyin gereksinimlerinin aile ya $\mathrm{da}$ ev ile eşgüdümlü biçimde ev dışından sağlamaktadır. Bakım gereksinimi olan yaşlılara dönük diğer bir sosyal bakım hizmeti kurumsal bakım olarak sağlanmaktadır. Kurumsal bakımda yaşlılara sağlık, sosyo-ekonomik ve psikolojik gereksinimleri bu konularda yetkinliği olan kişilerce sağlanmaktadır. Buna karşılık yaşlılara dönük diğer önemli bir bakım hizmeti, sosyal hizmet uzmanlarınınca daha genel ve kapsamlı biçimde sağlanmaktadır. Sosyal hizmet uzmanı evde bakım hizmetini sağlık, ev işleri gibi yaşlının gereksinimlerine göre eşgüdümlü biçimde sağlamaktadır. Son olarak yaşlilara yönelik sosyal organizasyonlardır. Bunlar, yaşlıların toplumla birbiriyle kaynaşmalarını sağlayan etkinliklerdir (Taşc1, 2010, s. 186).

Gelişmiş ülkeler yaşıı bakımını sosyal politikalardan bağımsız olmayacak biçimde sosyal güvenlik sistemlerinin güvence kapsamına almaktadır. Sosyal güvenlik sistemlerinde yaşlı bakımı iki sistem aracılığı ile sağlanmaktadır. İlki sosyal sigorta sistemi içinde primli sistem içinde bakım sigortası aracılığıyla sağlanmaktadır. Primli sistemin dışındakilere de primsiz sistem aracılığıyla sosyal hizmet ve sosyal yardım sistemleri aracılığıyla bakım sağlanmaktadır. İkincisi evrensel (Beveridge ) sosyal güvenlik sistemine sahip ülkelerde ödenen prime bakılmaksızın bakım hizmeti sağlanmaktadır.

Bu bağlamda, AB'nin gelişmiş üye ülkelerinde yaşlı bakımı emeklilik sistemi ya da yaşlılık aylığı, genel sağlık ve halk sağlığı ya da hastalık sigortası, bakım sigortası ya da sosyal hizmet ve yardımlar gibi kurumsal yapılarına göre farklılıklar görülse de, görece birbirine yakın nitelikte yaşlı bakım hizmetleri sağlanmaktadır.

\subsubsection{2. Çocuk Bakımı}

Çocuk bakımı refah devletleri için anahtar öneme sahiptir. Bu önemin ekonomik, sosyal ve politik pekçok nedeni olsa da işgücü piyasaları için temelde iki başlığ1 vardır. İlki, bir sonrakı kuşak olacak çocukların bakımı, eğitimi ve niteliği ya da 
yetkinliğgi işgücü piyasalarının insan değerinin düzeyini belirleyecektir. İkincisi, işgücü piyasalarına kadınların daha fazla katılımının artırılması ailelerin, işletmelerin ve devletlerin çocukların bakımın sağlayacağı düzeye ve kaliteye bağlıdır. Aksi durumda, çocuklarının bakımı sağlanmayan kadınların işgücü piyasasına katılımının olması pek olası değildir.

Zamanla ortaya çıkan değişmeler nedeniyle çocuk bakım hizmetleri gibi yeni sosyal politikaların geliştirilmesi (Bonoli, 2010, s. 9) özellikle kadınlar için önemlidir. Esnekleşmenin itiraz edilmeyen yönü olan kadının ailesine, yaşlı ve çocuk bakımına işten kalan zamanlarda bakması kapitalist sistemin kadınlar için biçtiği değer yargılarıdır. Oysa bir önceki dönemin en belirgin özelliği olan büyük işletmelerde kreş ve çocuk bakımının işçilere sağlanmasının ulusal yasalara bağlayıcı biçimde girmesine karşın, bu yeni dönemde kadının hem üretim sürecine içerilmesinin işgücünün kadınlaşması yoluyla sağlanması, hem de geri kalan zamanda ev işleri, çocuk, hasta ve yaşı bakımı ile uğraşması istenmektedir. Gelişmiş refah devletlerinde çocuk bakımının desteklenmesi, hasta ve yaşlı bakımının bakım sigortası çerçevesinde evde karşılanması artık yerini bu zorunlu aile hizmetlerinin devletin omuzlarından alıp kadının omuzlarına yüklenmesi anlamına gelmektedir. Dolayısıyla kadının evde bakım bekleyen çocuk, hasta ve yaşlı varken, tam süreli çalışmasını beklemek ve tam süreli çalışmadan mutlu olacağını beklemek doğası gereği olası değildir. Oysa çocuğun bakımının devletin gelir ve bakım desteği sağlayarak karşılanması ile kadın işgücü piyasasında kısmi süreli ve eğreti işlerde çalışmak yerine, tam süreli ve uygun işlerde çalışabilecektir.

Üye ülkelerde çocuk bakımına gereksinim enformel sektörün yükselişi ve aile içi nedenlerle artmaktadır. Anılan nedenler doğrultusunda çocuk bakımı için ailelere devlet desteğinin artırılması gerekmektedir (Mahon et al., 2012, s. 420).

Hollanda istisna olmak üzere, kısmi süreli istihdam genelde uzun süreli kısmi süreli istihdam anlamına gelmektedir. Kurumsal etmenlere bakıldı̆̆ında, cömert izin planları ve kamu çocuk bakım hizmetlerinin oranının yüksek olması kadınların işgücü piyasasında kalmaları için önemli etmenlerdir. AB üyesi ülkelerde Danimarka 
ve İsveç küçük çocuklar (üç yaş altı) için kamu çocuk bakımı alanında önderlik etmektedir. Bütün Kuzey ülkelerinde, Hollanda'da 13 aydan İsveç’te 18 aya değişen analık izni dışında ebeveyn izni seçenekleri de sağlanmaktadır. Bütün bu ülkeler ebeveynlere istekleri doğrultusunda çocuğun sekiz ya da dokuz yaşına kadar ebeveyn izni sağlamakta ve ebeveyn izinlerinde yürütebilecekleri kısmi süreli işlerde çalışma izni verilmektedir. Kuzey refah devletlerinin özellikle İsveç ve Danimarka'nın diğer bir özelliği babaların ebeveyn izni almaları konusunda cesaretlendirilmesidir. Bütün ülkeler ayrıca, aile üyelerinin ölmesi ya da hasta çocukların bakımı gibi acil durumları kapsayan aile izinleri için düzenlemeleri de sağlamaktadır. Kuzey ülkeleri bireysel nedenler ya da eğitim için işçilere izin vermektedir. Diğer $A B$ üyesi ülkelerle karşılaştırıldığında İsveç’te emeklilik yaşı oldukça yüksek ve çalışma yaşamının son bulması ileri yaşlara kadar sürmekte, 55-65 yaş arası insanların çoğu çalışmaktadır (Klammer, October 2006, s. 162).

İsveç ve Finlandiya arasında bakım konusunda önemli farklılıklar vardır. İsveç’te erkekler için bakım konusunda önemli teşviklere sahipken, Finlandiya'da küçük çocukların evde bakımının evde sağlanması ve çalışma arasında tercih yapma hakkının kurumsallaşması söz konusudur (Mahon et al., 2012, s. 420).

Kuzey sosyal demokrat refah devletinde özellikle Finlandiya ve İsveç’te ulusal çocuk bakım sistemleri evrensellik ilkesine dayalı olarak kamu eliyle finansmanının yürütümünün sağlandığı kaliteli bakım hizmetlerine sahiptir. Hatta bu ülkeler devletin etkinliğinin azaltıldığ 1 yetmişli yıllarda sosyal bakım hizmetini başarılı bir biçimde yürütmektedir. Ayrıca, bu ülkelerde devlet yapısının üniter olması yerel düzeyde herhangi bir gecikme olmaksızın ailelere bakım hizmetinin sağlanması için belediyelere kaynak aktarılmasını olanaklı kılmaktadır. Öte yandan bu iki ülke arasında yetmişli yıllarda Finlandiya'da kırsal yapılanma güçlü iken ve İsveç’te evrensel ve kamu ile yürütülmeyen ve desteklenmeyen bir çocuk bakımına sahip olmaları konusunda önemli farklılıklara sahipti. Yetmişli yıllarda Sosyal Demokrat ve Liberal Partinin dengelenmesi, feminist birliklerin baskıları sonucunda, İsveç hükümeti aile gündüz bakımevinden daha ucuz belediyelerce sağlanan bakım merkezlerini yaygınlaştırmıştır. İsveç’te çocukların yüzde 90'ından fazlası bakım 
merkezlerinde bakım hizmeti almaktadır. Öte yandan, Finlandiya'da üç yaşın altındaki çocukların yüzde 48'i ve üç yaştan okula başladıkları yedi yaşına kadar olan çocukların yüzde 30'u gündüz bakımevinde hizmet almaktadır (Mahon et al., 2012, s. 426).

Her iki ükede de kırsal bölgelerde anaerkil ve cinsiyet eşitliğinin olmasının etkisiyle Çocuk Evde Bakım Hizmetleri'ne erişim sağlanmaktadır. Finlandiya'da merkezi yönetim tarafından 1985 yılında çocuk bakım mevzuatında yardımını desteklenmektedir ve ebeveynler çocuk üç yaşına gelene kadar çocuk bakım izni alma haklar1 vardır (Mahon et al., 2012, s. 425).

İsveç’te 1996 yılında çocuk bakım politikalarının sorumlusu Eğitim Bakanlığı olmuş ve bir ve beş yaş aralığında çocuklar için eğitim müfredatı kabul edilmiştir. İsveç hükümeti 2002 yılında işsizlerin veya ebeveynlerin bir yere bırakmak zorunda kaldıkları çocukların bakım hizmetlerinin belediyeler tarafından karşılanmasını zorunluluk haline getirmiştir. 1998 y1lından sonra İsveç’te bütün çocuklar haftalık 15 saatlik okul öncesi eğitim alma hakkına sahip olmuştur. 2003 yılından sonra ise dört ve beş yaşlarındaki çocuklar evrensel ve ücretsiz okul öncesi eğitime sahiptir. Finlandiya'da ise 2000 y1lından sonra belediyelerin çoğunda okula başlamadan önceki yılda bütün çocuklara okul öncesi eğitim verilmektedir. Yeni liberal düşüncenin yayılması İsveç ve Finlandiya'daki meydan okumasının sonucunda, iki sisteminde piyasalaşmaya yönelmektedir. 1985 yılında ebeveynlerin çocuk bakım hizmetini özel kuruluşlardan alması sağlanmış, ancak sonraki 10 yılda bu oran yüzde beşte kalmıştır. 1997 yılında İsveç’te Sosyal Demokratlar yönetiminde koalisyon hükümeti tarafından özel kreş yardımı sağlanmış ve yüzde sekiz oranında çocuklar yararlandırılmıştır. Bütün bunlara rağmen, her iki ülkede de bakım hizmetlerinin özel kuruluşlar tarafindan sağlanması düşük oranda kalmaktadır. İsveç İşveren Sendikaları Konfederasyonu çocuk bakımı için bir işletmeyi (Pssylingen) kurarak, Stocholm bölgesinden başlayarak belediyeleri kapsayacak biçimde yaygınlaştırmıştır (Mahon et al., 2012, s. 426). Bakım hizmetlerinin özel kuruluşlar tarafından piyasadan sağlanmasının hükümetlerce desteklenmesi daha çok yaşlı bakımı için geçerli olmaktadır. 


\section{Sonuç}

Sanayi devriminden sonra üretim sürecine bağlı olarak işletmeler kitle üretimi yaparak ulusal sınırlar içinde gerçekleşmekte idi. Bu durum İkinci Dünya Savaşı sonrası daha da pekişmiş ve bireysel ve toplu iş mevzuatı, işçi sendikaları, toplu pazarlık gibi işgücü piyasası kurumlarının gelişimi artmıştır. Bu Fordist düzende iş ve gelir güvencesi mevzuatının yanı sıra sosyal güvenlik sistemleri işgücünü korumaktaydı. Ortaya çıkan ekonomik ve sosyal risklere karşı başta istihdam edilenleri koruyan düzenlemeler zamanla tüm toplumu koruyacak biçimde yapılandırılmıştır. Fordist üretime göre biçimlenen sosyal koruma düzenlemeleri ve işgücü piyasası kurumları post Fordizm olarak adlandırılan yetmişli yıllardan günümüze kadar olan dönemde değişime uğramıştır. Post Fordist dönemde petrol krizleri ve küresel mali krizler bir yandan işletmeleri esnekliği artırmaları yönünde baskılarken, diğer yandan işçilerin, işsizlerin ve tüm toplumun güvence gereksinimlerini de artırmaktadır. Bu büyük ekonomik değişimler sonucunda işgücü piyasalarının reformu gündeme gelmektedir.

$\mathrm{Bu}$ değişim süreçleri ile $\mathrm{AB}$ ülkelerinin işgücü piyasaları küreselleşme ile istikrarsızlaştırma ve düzensizleştirme süreçlerine girmektedir. Bu ülkelerin işgücü piyasalarındaki değişimden en çok kırılgan kümeler etkilenmektedir. AB ülkeleri sahip oldukları farklı refah devleti modellerine göre kırılgan kümelere sağladıkları sosyal yardımlar ve hizmetler bağlamında temel farklılıklar vardır. Özellikle kadınların işgücüne katılımlarının artması ile özel yaşam ve iş yaşamını bağdaştıracak uygulamalardan kaynaklanan yeni kavramlar ortaya çıkmaktadır. $\mathrm{Bu}$ kavramların başında güvenceli esneklik gelmektedir. İşgücü piyasalarının esnekleşmesi sonucu ortaya çıkan sorunların işçiler için güvenceli esneklik istihdam edilebilirlik ve gelir güvencesi gibi güvencelerle giderilmeye çalışılmaktadır.

Yeni liberal görüşün öngördüğü biçimde işgücü piyasalarında artan esneklik standart istihdam yerine atipik istihdam biçimlerini yaygınlaştırmaktadır. Sosyal güvenlik sistemlerinin sürekli ve tam süreli istihdama dayalı kurumsal ve mali yapılarla güvence sağlaması süreksiz ve kısmi süreli istihdamın artması ile birlikte sorunlar ortaya çıkmaktadır. Bu sorunlar temelde iki başlıkta toplanabilir. İlki, sosyal 
güvenlik sisteminin akçelendirilmesi ve sürdürülebilirliği zorlaşmaktadır. İkincisi, atipik biçimde istihdam edilenler işsizlik, analık sigortası gibi sosyal güvenlik sistemlerinin kapsamına alınmada asgari koşulları sağlayamama riski ile karşılaşabilmektedir. Gelişmiş $\mathrm{AB}$ ülkelerinde işgücü piyasalarının esnekleşmesi, düzensizleştirmesi ve istikrarsızlaştırılması kadınlar, gençler, yaşlılar, işsizler ve göçmenler için yeni güvencelerle korunmasını gerekli kılmaktadır.

$\mathrm{Bu}$ anılan kırılgan kümelerin korunması $\mathrm{AB}$ ülkelerinin sahip olduğu refah devleti modellerine göre farkl1lıklar göstermektedir. Anglo Sakson, Korporatist, Akdeniz ve İskandinav (Sosyal Demokrat Kuzey) refah devletleri kırılgan kümeleri korumak için farklı sosyal yardım ve hizmetleri uygulamaktadır. Bu refah devletlerinden Anglo Sakson ve Akdeniz refah devletleri, nüfusun yaşlanması meydan okumasına karşı Korporatist ve İskandinav refah devletlerinin uyguladığı sosyal yardım ve hizmetlerin kapsayıcılığı ve niteliği göre daha azdır. Akdeniz refah devleti modeline sahip ülkelerde bakım sigortası ya da bakım hizmetleri görece gelişmemişken, Anglo Sakson ülkelerde yaşılara yönelik sosyal yardımlar, sosyal hizmetler düşüktür. $\mathrm{Bu}$ nedenle gereksinimler piyasadan bireylerin kendi çabalarıyla karşılanmaktadır. Başta Almanya olmak üzere Korporatist refah devletlerinde bakım sigortası gelişmiştir. Almanya bakım için yeni sigorta sistemi oluşturmuş, yaşlıların bakımı sigorta kesenekleri ile sağlanmaktadır. İskandinav refah devletlerinde yaşlılara yönelik bakım hizmetleri genel bütçeden karşılanmakta ve tıbbi bakım olarak görülmektedir. Çocuklara yönelik sosyal yardım ve hizmetler çok buyutlu bir durumdur. İlk olarak refah devletlerindeki aile yardımlarının temel gerekçesi ve ölçütü çocuklara yönelik olmasıdır. $\mathrm{Bu}$ anlamda aile yardımları çocukları yoksulluktan kurtarmak için yapılmaktadır. İkinci olarak, kırılgan kümede yer alan kadınların işgücüne katılımınının artırılması çocuk bakımının refah devletince karşılanması ile olası olmaktadır. $\mathrm{Bu}$ anlamda işgücü piyasalarında esneklik ve güvencenin bağdaştrılmasında çocuk bakımı anahtar öneme sahiptir. Refah devletleri arasında çocuk bakım hizmetini merkezi hükümet, yerel yönetimler ve işletmeler tarafından karşılanmasında ya da bireylerin piyasadan doğrudan satın alma ile karşılaması yönünden farklılıklar vardır. Korporatist ve İskandinav refah devletlerinde çocuk bakım hizmeti merkezi hükümet, yerel yönetimler ve işletmeler tarafindan 
karşılanırken, Anglo Sakson ülkelerde görece doğrudan piyasadan satın alma yoluyla karşılanmaktadır. Akdeniz modeline sahip ülkelerde ise çocuk bakımının merkezi hükümet, yerel yönetimler ve işletmeler tarafından sağlanması görece zayıftır. Öte yandan çocuk bakımının piyasadan karşılanması, kadınların düşük gelir elde etmesi nedeniyle güçtür. Bu bağlamda, kadınların işgücüne katılımı başta İskandinav refah devleti modelindeki ülkelerde ve Korporatist refah devleti modelindeki ülkelerde yüksek iken, Anglo Sakson ve Akdeniz refah devleti modellerine sahip ülkelerde düşüktür. $\mathrm{Bu}$ anlamda, kırılgan kümelerin korunması bağlamında işgücü piyasalarında güvenceli esnekliğin düzeyi de yukarıdaki duruma benzerdir.

Not: $\mathrm{Bu}$ çalışma, Dokuz Eylül Üniversitesi Sosyal Bilimler Enstitüsü Çalışma Ekonomisi ve Endüstri İlişkileri Anabilim Dalı'nda Prof. Dr. Zeki ERDUT danışmanlığında hazırlanmakta olan “Avrupa Birliği ve Türkiye İşgücü Piyasalarında Esneklik ve Güvencenin Bağdaştırılması” başlıklı doktora tezinden türetilmiştir.

\section{Kaynakça}

(EC.), E. C. (2010). An Agenda for new skills and jobs: A European Contribution Towards Full Employment, Communication From The Commission To The European Parliament, The Council, The European Economic and Social Committee and The Committee of The Regions. (682 Final). Strasbourg,.

(KL), L. G. D. KL. (02.05.2013). Flexicurity- The Danish Model and the Local Governments, Retrieved from http://www.kl.dk/ImageVaultFiles/id_41696/cf_202/Report_Labour_Market_3.PDF.

Anner, M. (2015). Worker Resistance in Global Supply Chains: Wildcat Strikes, International Accords And Transnational Campaigns. International Journal of Labour Research: Decent Work in Global Supply Chains, 7( 1-2), 17-34.

Bales, K. (2002). Kullanıp Atılanlar”: Küresel Ekonomide Yeni Kölelik (P. Öğünç, Trans.Vol. 19). İstanbul,: Çitlembik Yayınları. 
Bart, C., \& Linden, B. V. d. (2009). Flexicurity in Belgium: A Proposal Based on Economic Principles. ZA Policy Paper, 1(9).

Bekker, S. (January 2013). The EU's Stricter Economic Governance: A Step Towards More Binding Coordination of Social Policies? (SP IV 2013-501). Berlin (WZB).

Bonoli, G. (2010). The Political Economy of Active Labour Market Policy. (RECWP 01/2010). Edinburgh: the Reconciliation of Work and Welfare in Europe (RECWOWE).

Campbell, P., Kelly, P., \& Harrison, L. (2011). Transitional Labour Market Programs: Challenges and Opportunities. Australia: Deakin University Alfred Deakin Research Institute.

Commission, E. (2010). An Agenda For New Skills And Jobs: A European Contribution Towards Full Employment. Retrieved from Strasbourg:

Cesur, E. E. (2016). Küresel Sermaye Hareketlerinin Türkiye'deki Gelir Dağılımına Etkisi, Türk Metal Sendikası Araştırma ve Eğitim Merkezi Yayınları - 6, Ankara.

Çağlar, T. (2015). Türkiye ve Almanya'da Karşılaştırmalı Yaşlı Bakım Model ve Uygulamalar1, Hacettepe Üniversitesi Sosyal Bilimler Enstitüsü, Yayınlanmamış Doktora Tezi, Ankara.

Dieckhoff, M., \& Gallie., D. (2007). The Renewed Lisbon Strategy and Social Exclusion Policy. Industrial Relations Journal, 38(6), 480-502.

Erdut, T. (2005). İşgücü Piyasasında Enformelleşme ve Kadın İşgücü. Çalışma ve Toplum, 6, 11-49.

Erdut, Z. (2004). Liberal Ekonomi Politikaları ve Sosyal Politika. Çalışma ve Toplum, 2004(2).

Eriksson, T. (2012.). Flexicurity and the Economic Crisis 2008-2009: Evidence from Denmark. (139). OECD Publishing.

Esping-Andersen.G. (1990). "The Three Political Economies of the Welfare State", The Three Worlds of Welfare Capitalism.Princeton-New Jersey: Princeton University Press.

Esping-Andersen, G. (2002). "Towards the Good Society, Once Again?”, Why We Need a New Welfare State. Oxford University Press. 
Esping-Andersen, G. (2007). Equal Opportunities and The Welfare State. Contexts, $6(3)$.

Eurofound. (21 March 2007).Varieties of flexicurity: reflections on key elements of flexibility and security, , Background Paper, Hearing on the Commission's Green Paper 'Modernising labour law to meet the challenges of the 21st century Sess

Eurostat. (2007). Measuring Progress Towards A More Sustainable Europe 2007 Monitoring Report of The EU Sustainable Development Strategy Eurostat Statistical Books. Luxembourg: European Union.

Eurostat. (2010, 03.01.2017). Employment rate of the total population, men and women, age group 20-64 in 2010, Eurostat, European Union. Retrieved from http://ec.europa.eu/eurostat/tgm/table.do?tab=table\&init=1\&plugin=1\&langu age $=$ en $\&$ pcode $=$ tesem 010

Fredman, S. (2004). Women at Work: The Broken Promise of Flexicurity. Industrial Law Journal, 33(4), 299-319.

Golden, T. D. (2008). Balancing the Implications of Employee Telework: Understanding the Impacts for Individuals and Organizations (Vol. 2). ABD: Sage Publication.

Harris, E. (2013). Financing Social Protection Floors: Considerations of Fiscal Space, The Role of National Social Protection Floors in Extending Social Security To All. International Social Security Review, 66(3-4), 111-143.

Hassel, A. (2003). The Governance of The Employment - Welfare Relationship in Britain and Germany (Edited by ), , First published 2001, 2003. In B. Ebbinghaus \& P. Manow (Eds.), Comparing Welfare Capitalism: Social policy and political economy in Europe, Japan and the USA. London: Routledge Taylor \& Francis e-Library. (Reprinted from: 2003).

Hemerijck, A. C. (2015). The quiet paradigm revolution of social investment. Social Politics, 22(2), 242-256. doi:DOI: 10.1093/sp/jxv009.

Hobson, B., \& Bede, L. (2015). Precariousness And Capabilities: Migrant Care/Domestic Workers In Two Institutional Contexts. Teorija in Praksa, 52(3), 327-349. 
Jensen, H., \& Larsen, J. N. (September 2005). The Nordic model: A recipe for European success?. In C. B. Schubert \& H. Martens (Eds.), EPC (European Policy Center) Working Paper (ss. 56-65). Retrieved from http://www.ugebreveta4.dk/upload/LO/Documents/F/flex.PDF.

Kanfer, R., \& Ackerman, P. L. (2008). Aging and Work Motivation (Vol. 2). ABD: Sage Publication.

Kawinski, M., \& Stanko, D. (2007). Labour flexibility and pension schemes in the European Union, , 5-7 March 2007,Social security Paper presented at the 5th International Research Conference on Social Security and the labour market: A mismatch?, Warsaw.

Keune, M. (2008). Flexicurity: a Contested Concept at the Core of the European Labour Market Debate", Flexicurity - a European Approach to Labour Market Policy. Intereconomics, March/April, 92-98.

Klammer, U. (October 2006). Flexicurity schemes Council of Europe, . Reconciling labour flexibility with social cohesion- Ideas for political action Trends in social cohesion, 16 (Workshop), 157-189.

Kuivalainen, S., \& Nelson, K. (2010). The Nordic Welfare Model in A European Perspective Working Paper (Vol. 11). Stockholm: Institute for Futures Studies.

Künzel, S. (2012). The Local Dimension of Active Inclusion Policy. Journal of European Social Policy, 22(1), 3-16. doi:10.1177/0958928711425270.

Langendonck, J. V., \& Put, J. (24.08.2015). Social Security Rights,Social Security Rights,ISSA (International Social Security Association) Reports, Retrieved from https://www.issa.int/html/pdf/initiative/reports/2ULeuven.pdf.

Lewis, H., Dwyer, P., Hodkinson, S., \& Waite, L. (2014). Hyper-precarious lives: Migrants, work and forced labour in the Global North. Progress in Human Geography, 39(5), 1-21.

Madsen, P. K. ( 2006). Flexicurity - A new perspective on labour markets and welfare states in Europe. Retrieved from Danmark:

Mahon, R., Anttonen, A., Bergqvist, C., Brennan, D., \& Hobson., B. (2012). Convergent care regimes? Childcare arrangements in Australia, Canada, Finland and Sweden. Journal of European Social Policy, 22(4), 419- 431. 
Manca, A. R., Governatori, M., \& Mascherini, M. (2010). Towards a set of Composite Indicators on Flexicurity. Luxembourg: Publication Office of the European Union.

Mayer, K. U. (2009). The Paradox of Global Social Change and National Path Dependencies: Life Course Patterns in Advanced Societies, 7-8. Retrieved from http://www.mpibberlin.mpg.de/en/institut/dok/full/ Mayer/theparad/Woodward_Kohli_eForm.pdf

Munck, R. (2013). The Precariat: a view from the South. Third World Quarterly, 34(5), 747-762.

OECD. (2006). Boosting Jobs and Incomes-Policy Lessons From Reassessing The OECD Jobs Strategy (Vol. Boosting). France: Organisation For Economic Co-Operation And Development (OECD) Publishing.

Pasnicu, D., \& Ciuca., V. (15.04.2013). Flexicurity: The Solution for Employment in Europe.Retrieved from http://www.spiruharet.ro/sesiunicomunicari/word/1.4.pdf

Pollert, A., \& Charlwood, A. (2009). The vulnerable worker in Britain and problems at work. Work, Employment and Society, 23(2), 343-362.

Räisänen, H., \& Schmid, G. (2008). Transitional Labour Markets and Flexicurity From The Finnish Labour Market Point of View, Discussion Paper Retrieved from Wissenschaftszentrum Berlin für Sozialforschung (WZB):

Reci, I., \& Bruijn, J. d. (2006). Transitional Labour Markets: Past, Present and Future Applications, Social Policy Research. Retrieved from Amsterdam:

Rogowski, R. (2008). Transitional Labour Markets and the Europian Social model. In R. Rogowski (Ed.), The European Social Model and Transitional Labour Markets: Law and Policy. New York: Taylor\&Francis.

Schmid, G. (1998). Transitional Labour Markets: A New European Employment Strategy, Discussion Paper Retrieved from Berlin:

Schmid, G. (May 2014). Inclusive Growth: What Future for the European Social Model?

Sen, A. (June 2000). Social Exclusion: Concept, Application, And Scrutiny. Retrieved from Manila: 
Sözer, A. N. (1997). Sosyal Devlet Uygulamaları: Almanya, İngiltere, Hollanda ve Türkiye Sosyal Devlet (Vol. 8). İzmir: Cemiyet Yayınları.

Tangian, A. (November 2009). Six Families of Flexicurity Indicators Developed at the Hans Boeckler Foundation. Retrieved from Duesseldorf:

Tangian, A. (October 2004). Liberal and Trade-Unionist Concepts of Flexicurity: Modelling in Application to 16 European Countries. Retrieved from Düsseldorf:

Taşcı , F. (2010). Yaşlılara Yönelik Sosyal Politikalar: İsveç, Almanya, İngiltere ve İtalya Örnekleri. Çalışma ve Toplum, Sayı: 2010/1, ss. 175-202.

Torka, N. \& Velzen, M. V. (2008). Flexible Labor. In C. Wankel (Ed.), 21st Century Management A Reference Handbook (Vol. 2, ss. 93-103). ABD: Sage Publication.

Van Ginneken, W. ( 2013). Social Protection For Migrant Workers: National And International Policy Challenges. European Journal of Social Security, 15(2), 209-221.

Vandenberg, P. (September 2010). Impact of Labor Market Institutions on Unemployment: Results from a Global Panel. Economics Working Paper Series. Metro Manila.

Vielle, P., \& Walthery, P. (2003). Flexibility and Social Protection, Foundation project: Negotiating the conditions of flexibility, Research management: Agnès Parent-Thirion. Dublin.

Werner, W. (2006). The European Social Model: Cause of, or Solution to, the Present Crisis of the European Union?”, Forum: Which Socio-economic Model for Europe? Intereconomics, January/February, 4-20.

Wilthagen, T. \& Tros, F. (2004). The Concept of 'Flexicurity': A New Approach to Regulating Employment and Labour Markets. Transfer: European Review of Labour and Research, 2(4), 166-186.

Yeldan, E. \& Yıldırım D. (2015.). Küreselleşme ve Sanayisizleşme Bağlamında Türkiye'de ve Dünyada Demokrasi Açı̆̆ı. Çalışma ve Toplum, 2015/2, 6588. 
Zirra, D. (2012). Evolution and Trends of Flexicurity in the Current Context of Economic and Social Development. Romanian Economic and Business Review, 7(1), 60-74. 